\title{
Efficacy of Probiotics in Patients of Cardiovascular Disease Risk: A Systematic Review and Meta-Analysis
}

\author{
Asher Dixon, ${ }^{1,2,4}$ Kai Robertson, ${ }^{3}$ Amanda Yung, ${ }^{2}$ Michael Que, ${ }^{2}$ Hayden Randall, 2,4 \\ Don Wellalagodage, ${ }^{2,4}$ Tynan Cox, ${ }^{1}$ Dylan Robertson, ${ }^{1}$ Cheng Chi, ${ }^{1}$ and Jing Sun, 1
}

\author{
${ }^{1}$ School of Medicine, Griffith University, Gold Coast, Queensland, Australia; ${ }^{2}$ Sydney Medical School, \\ University of Sydney, Camperdown NSW; ${ }^{3}$ School of Medical Science, Griffith University ${ }^{4}$ St Paul's College \\ Graduate House, Sydney, Australia
}

Correspondence: Associate Professor Jing Sun, School of Medicine, Griffith University, Gold Coast campus. Q4222 Email: j.sun@griffith.edu.au

\begin{abstract}
:
Purpose of Review: This meta-analysis evaluated the effect of probiotics on blood pressure, blood glucose, body mass index (BMI), and lipid profile of patients with cardiovascular disease risk factors.
\end{abstract}

Recent Findings: Randomised controlled trials published on PubMed, Scopus, Embase, Grey Literature and the Cochrane Central Register of Controlled Trials (CENTRAL) from 1990 to 2020 were systematically searched. The PEDro scale was used to assess the quality of studies. A total of 34 studies with 2,177 adults were selected for inclusion in the analysis. The mean difference and effect size with a 95\% confidence interval (CI) were analysed for the pooled results. Statistically significant pooled effects of probiotics were found in the reduction of SBP by $-1.31 \mathrm{mmHg}(95 \% \mathrm{CI}:-2.23,-0.39, \mathrm{P}=0.005), \mathrm{DBP}$ by $-1.87 \mathrm{mmHg}$ (95\% CI: $-2.41,-1.33, \mathrm{P}<0.001)$, total cholesterol by $-6.05 \mathrm{mg} / \mathrm{dL}(95 \% \mathrm{CI}:-8.49,-3.61, \mathrm{P}<$ $0.001)$, LDL-C by $-8.77 \mathrm{mg} / \mathrm{dL}$ (95\% CI: $-11.86,-5.69, \mathrm{P}<0.001)$, serum glucose by -4.92 $\mathrm{mg} / \mathrm{dL}(95 \% \mathrm{CI}:-6.15,-3.69, \mathrm{P}<0.001)$, HbA1C by $-0.18 \%(95 \% \mathrm{CI}:-0.31,-0.06, \mathrm{P}=$ $0.005)$, and BMI by $-0.31 \mathrm{~kg} / \mathrm{m}^{2}(95 \% \mathrm{CI}:-0.41,-0.21, \mathrm{P}<0.001)$. No significant changes were observed in the outcome of triglycerides and HDL-C.

Summary: Probiotic supplementation had beneficial effects on blood pressure, blood glucose, BMI, and lipid profile levels in patients with cardiovascular disease risk factors. These effects were associated with longer treatment duration, higher dosage, use of alternate formulations, diabetic patients, and female populations.

Keywords: Probiotics, Cardiovascular Disease, Hypertension, Diabetes, Microbiome

\section{Introduction:}

Cardiovascular disease (CVD) is the leading cause of death worldwide. In 2016, CVDs were responsible for approximately 17.9 million deaths, or $31 \%$ of all deaths globally [1]. By 2025 , over 5 million men and 2.8 million women are projected to die prematurely from CVD [2]. The most prominent physiological risk factors for CVDs are a cluster of medical conditions known as 
metabolic syndrome. This "deadly quartet" of metabolic abnormalities include obesity, glucose intolerance/insulin resistance, dyslipidaemia, and hypertension [3].

The presence of cardiovascular-risk factors, or any one of its components, confers a greatly increased risk of developing CVD, including ischaemic heart disease and stroke [4]. While there are variable definitions of cardiovascular disease risk such as metabolic syndrome, it is estimated to be prevalent in approximately one quarter of the world population, putting a significant proportion of humanity at risk of developing CVD [5]. Thus, CVDs and its associated comorbidities represent a significant burden to world health.

Currently, CVD risk reduction is commonly managed by medications such as statins and antihypertensives [6]. Control of risk factors for CVD can also be achieved through lifestyle modification, especially through diet and exercise. For instance, lowering salt intake has been shown to reduce blood pressure substantially [7]. However, due to the immense and evergrowing burden of CVDs, alternative approaches are required in the coming years to reduce morbidity and mortality associated with CVDs.

The past decade has seen an upsurge of interest in the contribution of the human microbiome to health and disease. The human gastrointestinal microbiota is incredibly diverse [8] and plays key roles in maintaining the gastrointestinal epithelium, modulation of the immune system, digestion, and nutrient metabolism [9] Alteration of the microbiota in a pathological fashion, known as dysbiosis, may be involved in the pathogenesis of many diseases, including inflammatory bowel disease [10], cancer [11], obesity [12], and diabetes mellitus [13]. Dysbiosis itself can be caused by medical and lifestyle factors such as infection, host genetics, antibiotic use, and a high-fat, low-fibre diet [14]. Crucially, there have also been studies linking dysbiosis to hypertension, insulin resistance, dyslipidaemia, and increased adiposity [15] [16], thus raising the possibility of managing CVD risk factors by treating dysbiosis.

One method of treating dysbiosis is by probiotics. Probiotics, formally defined as "live microorganisms that, when administered in adequate amounts, confer a health benefit on the host" [17], have shown efficacy in helping prevent or alleviate gut-related disorders such as irritable bowel syndrome [18], diarrhoea [19][20], colorectal cancer [21], and lactose intolerance [22]. The most common strains used in probiotics are lactic acid bacteria belonging to genera Lactobacillus, Enterococcus, and Bifidobacterium [23]. Possible mechanisms by which probiotics exert their effect include restoring microbiota diversity, decreasing cholesterol absorption, reducing the production of pro-inflammatory molecules, and the synthesis of various metabolites [24][25]. Probiotics are most frequently consumed in the form of food or drink, such as yogurts, or as dietary supplement pills [26]. Probiotic studies have also shown promising results in treating hypertension, dyslipidaemia, insulin resistance, and obesity, with potential to have protective and therapeutic effects against heart failure and myocardial infarction $[27 *][28][29]$.

Patients with CVD risk factors, such as metabolic syndrome, face a greatly increased risk of cardiovascular events and may therefore have the greatest potential for benefit from probiotic therapy. Thus, our systematic review and meta-analysis aims to elucidate whether probiotic therapy is effective in lowering the physiological and biomedical risk factors of CVD (namely obesity, blood pressure, blood glucose, and lipids) in patients who are afflicted by cardiovascular comorbidities such as hypertension, Type II diabetes, obesity, and dyslipidaemia. 


\section{Methods:}

Search Methods: The review protocol was registered with the Prospero International Prospective Register of Systematic Reviews

(http://www.crd.york.ac.uk/prospero/display_record.php?ID = CRD42014010591); registration number CRD2014010591 [29]. The Population, Intervention, Control, Outcome (PICO) principle was used to search the literature [30]. The population was hypertensive adults $>18$ years of age with cardiovascular disease risk, metabolic syndrome, type II diabetes mellitus, hypertension, obesity, hypercholesterolaemia. The intervention was probiotic supplementation treatment within the intervention group; the control included patients receiving no treatment, placebo or alternate cardiovascular medications; the primary outcomes used were blood pressure, cholesterol, triglycerides, fasting blood glucose, H1bA1C, LDL-C, HDL-C and the secondary outcome was BMI. The keywords used to identify relevant studies through advanced searches were as follows: Hypertension AND (Cardiovascular Disease OR Metabolic Syndrome OR Diabetes) AND Probiotic Agent AND Randomised Controlled Trial. For cases where data was not adequately reported, authors were contacted in order to retrieve the necessary information.

Inclusion Criteria: Inclusion of studies within the meta-analysis followed strict inclusion criteria as follows: (1) Published in a peer-reviewed journal in the past 30 years or Grey Literature (February 1990 until February 2020); (2) Study design was an RCT; (3) Participants were adult patients with hypertension, obesity, cardiovascular disease, metabolic syndrome, type II diabetes or hypercholesterolaemia; (4) probiotics were used as an intervention approach; (5) primary outcome variables included blood pressure, Total cholesterol, HbA1C, serum glucose, LDL-C, HDL-C with BMI as an additional outcome; (6) If multiple studies were published on the same population only the most recent study is to be included.

Data Collection: Studies that reported insufficient or incomplete data had their corresponding authors contacted, seeking acquisition of necessary additional data. No authors provided information on outcomes for studies and their values were excluded in the analysis.

Data Extraction: Two authors completed the initial search with review of each search strategy, three authors resolved disagreements. AD completed the first search with AY completing a paralleled search. DR participated in discussion when disagreements were raised. All citations and abstracts were downloaded to EndNote X9 for review. Duplicates were deleted and the titles and abstracts of the remaining articles were screened for inclusion and checked by a second examiner (Figure 1. outlines this process). Several databases were used to identify articles for inclusion such as PubMed, Scopus, Embase, Grey Literature and the Cochrane Central Register of Controlled Trials (CENTRAL). The following data were extracted from each of the included articles: study setting, design location, study blinding, participant demographics, attrition rate, comorbidities, participant age \& gender, probiotic treatment duration \& route, strain and form of probiotic used for intervention, dosage of intervention treatment, control used, measured outcomes, information for assessment of the risk of bias and reported major findings.

Quality Assessment: The Physiotherapy Evidence Database tool (PEDro scale) was used to rapidly assess the internal validity (criteria 2-9), external validity (criteria 1) and sufficiency of statistical information (criteria 10-11) of randomised clinical trials. The Pedro tool categorises the quality of studies into three levels: high quality ( $\geq 8$ points), moderate quality 
(4-7 points), and low-quality ( $\leq 3$ points). Criteria 1-11 are as follows: eligibility criteria specified, subject randomisation, allocation concealment, the similarity of baseline prognosis between groups, blinding of subjects, therapists and assessors, a primary outcome measurement on $\geq 85 \%$ of initial subjects, use of intention-to-treat analysis, use of variability measures and use of between-group comparison methods. Each paper was assessed independently by two reviewers and any discrepancies were resolved via discussion (Table $1)$.

Statistical Analysis: The effect of probiotics on CV health outcome variables was described with the use of a pooled effect sized method. Random - effect meta-analyses were performed to describe the overall effect size. Mean difference was used to present the effect size for blood pressure, total cholesterol, LDL-C, HDL-C, triglycerides, serum glucose, HbA1c and BMI. CIs and the weighted mean difference were calculated for each outcome variable. Analysis of each study to assess for inconsistency included; visual assessment of CI for overlap and $I^{2}$ statistics of heterogeneity. Subgroup analyses were performed including gender ratio (Female $>$ Male, Male $>$ Female), dosage of probiotics $\left(<1.0 \times 10^{9} \mathrm{CFU}\right.$ compared with $\left.>1.0 \times 10^{9} \mathrm{CFU}\right)$, attrition $(>15 \%$ compared with $<15 \%$ ), form of probiotic (Capsule, Milk, Yogurt, Other), study blinding (SB, DB and NB) and duration of study $(<1.5$ months compared with $>1.5$ months). It can be noted, study numbers within the subgroup tables (3-7) represent the total number of studies included within each paper. As such individual papers may have included more than one study. Publication bias was assessed using Egger's Test (Table 8).

Figure 1. PRISMA flow chart
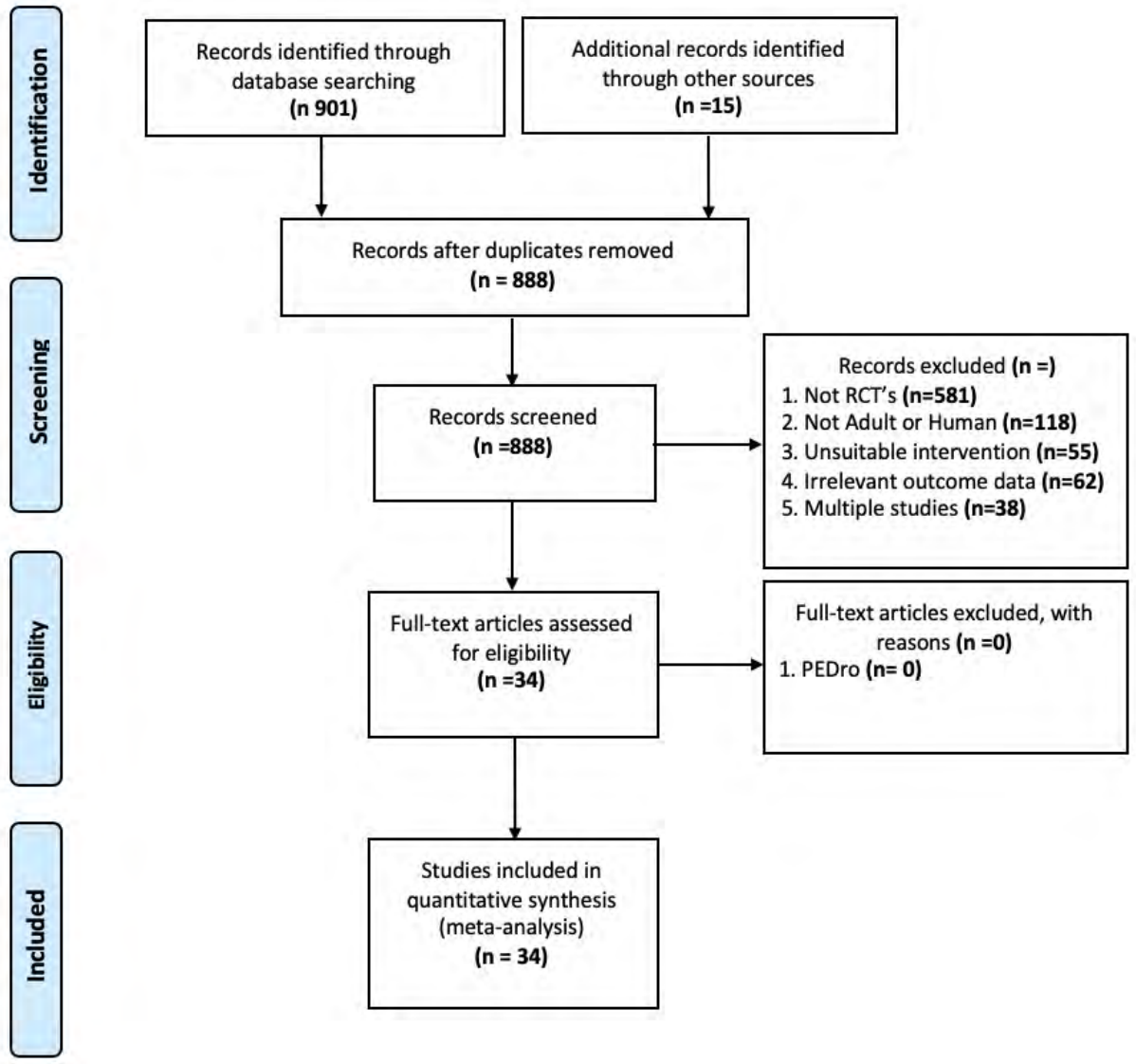


\section{Results:}

The initial database search yielded 901 potential articles and 15 additional articles were found through the reference lists of published articles. Duplicate articles (28) were removed. A total of 888 studies remained for screening through abstract and title for relevant articles to the study. Application of the Physiotherapy Evidence Database process confirmed the remaining selection of 34 studies to be included in the final Meta-Analysis (Table 1).

Participants: An outline of included studies are provided in Table 2. Outcomes were reported on 2,177 adults receiving probiotic intervention (1176) or control (1001) with removal of duplicate controls. Probiotics treatment was used to assess different cardiovascular outcomes, with ten studies measuring blood pressure $(38,43,45,51,52,55,57,59,60,64)$; twenty-four studies measuring total cholesterol $(31,33,34,35,38,39,41,42,43,44,45,49,50,51,52$, $55,56,57,59,60,61,62,63)$;twenty-one studies measuring LDL-C $(31,32,33,34$ 35, 39, $41,43,44,45,49,50,52,55,56,57,58,59,60,61,63)$; twenty-three studies measuring HDL-C (31, 32, 33, 34 35, 39, 40, 41,43, 44, 45, 49, 50, 51, 52, 55, 56, 57, 58, 59, 60, 61, $63)$; twenty five studies measuring triglycerides $(31,33,34,35,37,38,39,41,42,43,44,45$, $49,50,51,52,55,56,57,59,60,61,62,63)$; twenty studies measuring serum glucose $(33$, $35,36,37,38,41,42,45,47,49,50,52,53,55,56,57,58,59,61,62,63)$; sixteen studies measuring $\operatorname{HbA} 1 \mathrm{C}(33,35,36,38,39,41,45,47,49,50,52,53,54,55,56,59)$; and nineteen studies measuring BMI $(33,35,38,39,41,45,46,48,49,50,52,53,54,57,58,60,61,63$, 64). These studies were conducted in 11 different locations, including Australia (43), Brazil (34, 39), Czech Republic (44), Denmark (32), Estonia (60), Iran (31,33 35, 36, 37, 47, 49, 50, $53,54,56,57,58,59,61,63,64)$, Japan $(40,41,42,46,51,55)$, Korea (45, 58), Malaysia (38), Poland (62) and Sweden (52).

Effect on Blood Pressure: Ten studies with a total sample of 755 adults measured the mean difference of blood pressure between the intervention and control groups. The meta-analysis showed there was a statistically significant difference in the mean systolic and diastolic blood pressure, with an overall difference of $-1.31 \mathrm{mmHg}(95 \% \mathrm{CI}:-2.23,-0.39)$ in SBP $(P=$ $0.005)$ and $-1.87 \mathrm{mmHg}(95 \% \mathrm{CI}:-2.41,-1.33)$ in DBP $(P<0.001)$ in favour of probiotic intervention. The heterogeneity was not statistically significant $\left(I^{2}=0 \%, P=0.48\right)$. The forest plot of the effect is presented in Figure 2A and Figure 2B. A subgroup analysis (Table 3 ) found the effect of probiotics on SBP and DBP was more statistically significant in patients with Diabetes Mellitus demonstrating a $5.82 \mathrm{mmHg}$ reduction in SBP $(P=0.02)$ and a $3.81 \mathrm{mmHg}$ reduction in DBP $(P<0.001)$. Probiotics were more effective when in yoghurt form, reducing SBP and DBP by $3.56 \mathrm{mmHg}(P=0.07)$ and $3.54 \mathrm{mmHg}(P=0.001)$ respectively. SBP reductions of $2.38 \mathrm{mmHg}(P=0.04)$ were observed in patients treated for $>1.5$ months. Probiotics appeared more effective on SBP and DBP in male populations demonstrating reductions of $2.36 \mathrm{mmHg}(P=0.05)$ and $0.81 \mathrm{mmHg}(P=0.007)$ respectively. A reduction in DBP was observed in both long and short duration patient groups, with DBP reductions of $1.98 \mathrm{mmHg}(P=0.01)$ and $2.14 \mathrm{mmHg}(P=0.001)$ respectively. Subgroup comparisons between dosage, blinding, attrition and hypertensive or hypercholesterolaemic patients could not be calculated due to lack of data.

Effect on Total Cholesterol: Twenty-four studies with a total sample of 1,727 adults measured the mean difference in cholesterol between the intervention and control. The metaanalysis showed there was a statistically significant difference in the mean cholesterol, with an overall difference of $-6.05 \mathrm{mg} / \mathrm{dL}(95 \% \mathrm{CI}:-8.49,-3.61)$ in Total cholesterol $(\mathrm{P}<0.001)$ in favour of probiotic intervention. The heterogeneity was not statistically significant $\left(I^{2}=\right.$ 
$0 \%, P=0.80)$. The forest plot of the effect is presented in Figure 2C. A subgroup analysis (Table 4) detected a cholesterol reduction of $16.54 \mathrm{mg} / \mathrm{dL}(P<0.001)$ in

hypercholesterolaemic patients. A significant reduction in serum cholesterol was recorded in patients treated for $<1.5$ months, $-11.61 \mathrm{mg} / \mathrm{dL}(P<0.001)$, and $>1.5$ months, $-4.84 \mathrm{mg} / \mathrm{dL}$ $(P<0.001)$. Patients that received probiotics in yoghurt, milk and other forms (e.g. kefir and powder) had significant reductions in serum cholesterol: $-9.48 \mathrm{mg} / \mathrm{dL}(P=0.006),-8.74$ $\mathrm{mg} / \mathrm{dL}(P=0.004)$, and $-5.22 \mathrm{mg} / \mathrm{dL}(P=0.003)$ respectively. Probiotics were more effective in reducing cholesterol in predominantly male patient groups than predominantly female patient groups with reductions of $6.44 \mathrm{mg} / \mathrm{dL}(P=0.01)$ and $5.59 \mathrm{mg} / \mathrm{dL}(P=0.002)$ respectively. Double blinded studies reported a statistically significant reduction in cholesterol of $6.43 \mathrm{mg} / \mathrm{dL}(P<0.001)$. A reduction in cholesterol was apparent in patients receiving higher dosages $\left(>1.0 \times 10^{9} \mathrm{CFU}\right)$ of probiotics, $-6.38 \mathrm{mg} / \mathrm{dL}(P<0.001)$. Studies with lower attrition rates $(<15 \%)$ reported a more significant reduction in serum cholesterol, $6.01 \mathrm{mg} / \mathrm{dL}(P<0.001)$. Subgroup comparisons in Non-blinded studies could not be calculated due to a lack of data.

Effect on $\boldsymbol{L D L}-\boldsymbol{C}$ : Twenty-one studies with a total sample of 1,526 adults measured the mean difference in LDL between the intervention and control. The meta-analysis showed there was a statistically significant difference in LDL, with an overall difference of $-8.77 \mathrm{mg} / \mathrm{dL}(95 \%$ CI: -11.86, -5.69), $(\mathrm{P}<0.001)$ in favour of probiotic treatment. There is evidence of moderate heterogeneity $\left(I^{2}=78 \%, P<0.001\right)$. The forest plot of the effect is presented in Figure $2 \mathrm{H}$. A subgroup analysis (Table 5) found the effect of probiotics on LDL-C was more statistically significant in patients with Hypercholesterolaemia demonstrating a $-20.67 \mathrm{mg} / \mathrm{dL}$ reduction $(P=0.001)$. Patients with diabetes and obesity were close to follow with reductions in LDL$\mathrm{C}$ of $-8.09 \mathrm{mg} / \mathrm{dL}(P=0.03)$ and $-7.27 \mathrm{mg} / \mathrm{dL}(P=0.001)$ respectively. When administered as yoghurt, probiotics demonstrated a significant decline in LDL-C of $-18.06 \mathrm{mg} / \mathrm{dL}(P=$ 0.001). Milk and capsule form similarly showed significant reductions in LDL-C of -9.82 $\mathrm{mg} / \mathrm{dL}(P=0.007)$ and $-4.35 \mathrm{mg} / \mathrm{dL}(P=0.001)$. Shorter durations of treatment $(<1.5$ months) proved to have significant reductions in LDL-C $-14.01 \mathrm{mg} / \mathrm{dL}(P=0.001)$. Studies with treatment duration $>1.5$ months similarly proved to reduce LDL-C $(-7.08 \mathrm{mg} / \mathrm{dL},(P=$ $0.001)$. A greater reduction in LDL-C was apparent in patients receiving higher dosages $(>$ $\left.1.0 \times 10^{9} \mathrm{CFU}\right)$ of probiotics, $-8.38 \mathrm{mg} / \mathrm{dL}(P=0.001)$. Probiotics were more effective in lowering LDL-C in patient groups that were predominantly female, demonstrating a -9.87 $\mathrm{mg} / \mathrm{dL}(P=0.001)$ Subgroup comparisons on the blinding of studies and attrition could not be calculated due to a lack of data.

Effect on HDL-C: Twenty-three studies with a total sample of 1,602 adults measured the mean difference in HDL-C between the intervention and control. The meta-analysis showed there was no statistically significant difference in HDL-C, with an overall difference of 1.05 $\mathrm{mg} / \mathrm{dL}(95 \% \mathrm{CI}:-0.33,2.43),(\mathrm{P}=0.14)$. There is evidence of severe heterogeneity $\left(I^{2}=\right.$ $90 \%, P<0.001)$. The forest plot of the effect is presented in Figure 2I. A subgroup analysis (Table 5) found that probiotics were most effective in Hypercholesterolaemic and Diabetic patients with an increase in HDL-C of $6.36 \mathrm{mg} / \mathrm{dL}(P=0.04)$ and $2.03 \mathrm{mg} / \mathrm{dL}(P=0.01)$ respectively. It can be noted that obese patients sustained a reduction in HDL-C of -1.21 $\mathrm{mg} / \mathrm{dL}(P=0.001)$. Similarly, patient groups that were predominately female indicated significant reductions of HDL-C $-1.02 \mathrm{mg} / \mathrm{dL}(P=0.02)$. The remaining data revealed that probiotic treatment did not elicit a significant difference in HDL-C between subgroups: Dosage, formulation, study duration. Subgroup comparisons on the blinding of studies and attrition could not be calculated due to a lack of data. 
Effect on Triglycerides: Twenty-five studies with a total sample of 1,590 adults measured the mean difference in cholesterol between the intervention and control. The meta-analysis showed there was no statistically significant difference in the mean serum triglycerides in patients taking probiotics with an overall difference of $3.24 \mathrm{mg} / \mathrm{dL}(95 \% \mathrm{CI}$ : $-0.07,6.54),(P$ $=0.06)$. There is evidence of moderate heterogeneity $\left(I^{2}=61 \%, P<0.001\right)$ within the study sample. The forest plot of the effect is presented in Figure 2D. A subgroup analysis (Table 4) detected a triglyceride reduction of $14.17 \mathrm{mg} / \mathrm{dL}(P=0.02)$ in Diabetes Mellitus patients treated with probiotics. The remaining data revealed that probiotic treatment did not elicit a significant difference in serum triglycerides between subgroups: sex, dosage, attrition, formulation, blinding or study duration. Subgroup comparisons in Non-blinded studies could not be calculated due to a lack of data.

Effect on Fasting Glucoses: Twenty studies with a total sample of 1,481 adults measured the mean difference in serum fasting glucose between the intervention and control. The metaanalysis showed there was a statistically significant difference in serum glucose, with an overall difference of $-4.92 \mathrm{mg} / \mathrm{dL}(95 \% \mathrm{CI}:-6.15,-3.69),(\mathrm{P}<0.001)$ in favour of probiotic treatment. There is evidence of substantial heterogeneity $\left(I^{2}=83 \%, P<0.001\right)$ within the study sample. The forest plot of the effect is presented in Figure 2E. A subgroup analysis (Table 6) detected a serum fasting glucose reduction of $16.15 \mathrm{mg} / \mathrm{dL}(P=0.001)$ in short term treatment models where patients were treated for $<1.5$ months with probiotics. Patients that received probiotics in capsule, yoghurt and other forms (e.g. kefir and powder) had significant reductions in serum fasting glucose: $-13.47 \mathrm{mg} / \mathrm{dL}(P=0.03),-12.88 \mathrm{mg} / \mathrm{dL}(P=$ $0.03)$ and $4.41 \mathrm{mg} / \mathrm{dL}(P=0.001)$ respectively. It was also observed that probiotics reduced serum fasting glucose by $12.94 \mathrm{mg} / \mathrm{dL}(P<0.001)$ in Diabetes Mellitus patients treated with probiotics. Subgroup analysis revealed a greater reduction of serum fasting glucose in predominantly male patient groups, $-5.69 \mathrm{mg} / \mathrm{dL}(P=0.001)$. A greater reduction in serum glucose was apparent in patients receiving higher dosages $\left(>1.0 \times 10^{9} \mathrm{CFU}\right)$ of probiotics, $5.29 \mathrm{mg} / \mathrm{dL}(P=0.001)$. Double blinded studies reported a serum fasting glucose reduction of $5.27 \mathrm{mg} / \mathrm{dL}(P=0.001)$. No significant changes in fasting glucose could be identified between groups of attrition, with a $-5.63 \mathrm{mg} / \mathrm{dL}(P=0.001)$ reduction in $>15 \%$ attrition and a $-5.29 \mathrm{mg} / \mathrm{dL}(P=0.001)$ reduction in $<15 \%$ attrition. Subgroup comparisons in nonblinded studies and patients with hypertension or hypercholesterolaemia could not be calculated due to a lack of data.

Effect on HbA1C: Sixteen studies with a total sample of 1,122 adults measured the mean difference in $\mathrm{HbA} 1 \mathrm{C}$ between the intervention and control. The meta-analysis showed there was a statistically significant difference in $\mathrm{HbA1C}$, with an overall difference of $-0.18 \%$ (95\% CI: $-0.31,-0.06),(\mathrm{P}=0.005)$ in favour of probiotic treatment. There is evidence of substantial heterogeneity $\left(I^{2}=92 \%, P<0.001\right)$. within the study sample. The forest plot of the effect is presented in Figure 2F. A subgroup analysis (Table 6) demonstrated that yoghurt probiotic formulations reduced $\mathrm{HbA} 1 \mathrm{C}$ by $55 \%(P=0.03)$, statistically significant reductions were not seen in other formulations. It was also found probiotics were more effective in reducing $\mathrm{HbA} 1 \mathrm{C}$ in patients treated for $<1.5$ months, $-50 \%(P=0.001)$. Furthermore, serum HbA1C was reduced by $32 \%(P=0.04)$ in patients within the 'other' health group (e.g. multiple comorbidities, such as metabolic syndrome). Studies with higher attrition rates $(>15 \%)$ demonstrated a slightly larger reduction in $\mathrm{HbA1C},-20 \%(P=0.01)$, when compared with lower attrition rate studies $(<15 \%),-19 \%(P=0.001)$. Probiotics were more effective at reducing $\mathrm{HbA} 1 \mathrm{C}$ in patient groups that were predominantly female, with a reduction of $18 \%$ $(P<0.001)$. Subgroup analysis revealed there was a more promising trend in the reduction of HbA1C in higher doses $\left(>1 \times 10^{9} \mathrm{CFU}\right)$ of probiotics, $-12 \%(P=0.06)$, than lower doses. 
Subgroup comparisons of study blinding and patients with hypertension or hypercholesterolaemia could not be calculated due to a lack of data.

Effect on BMI: Nineteen studies with a total sample of 1,205 adults measured the mean difference in BMI between the intervention and control. The meta-analysis showed there was a statistically significant difference in BMI, with an overall difference of $-0.31 \mathrm{~kg} / \mathrm{m}^{2}(95 \%$ CI: -0.41, -0.21), $(\mathrm{P}<0.001)$ in favour of probiotic treatment. The heterogeneity was not statistically significant $\left(I^{2}=0 \%, P=0.51\right)$. The forest plot of the effect is presented in Figure $2 \mathrm{G}$. A subgroup analysis (Table 7) found that probiotics were able to reduce BMI by 0.50 $\mathrm{kg} / \mathrm{m}^{2}(P=0.001)$ when administered in other forms (e.g. kefir and powder). Probiotics were also able to reduce BMI by $0.48 \mathrm{~kg} / \mathrm{m}^{2}(P=0.001)$ in patients with obesity. A greater reduction in $\mathrm{BMI}$ was apparent in patients receiving higher dosages $\left(>1.0 \times 10^{9} \mathrm{CFU}\right)$ of probiotics, $-0.41 \mathrm{~kg} / \mathrm{m}^{2}(P=0.001)$. Probiotics were more effective in lowering BMI in patient groups that were predominantly female, demonstrating a $0.35 \mathrm{~kg} / \mathrm{m}^{2}(P=0.001)$ reduction in $\mathrm{BMI}$ in these groups. It was also found probiotics were more effective in lowering BMI in patients treated for $>1.5$ months, $-0.31 \mathrm{~kg} / \mathrm{m}^{2}(P=0.001)$. Studies with lower attrition rates $(<15 \%)$ reported a significant reduction in BMI, $-0.29 \mathrm{~kg} / \mathrm{m}^{2}(P=0.001)$. Subgroup comparisons on the blinding of studies could not be calculated due to a lack of data.

Publication Bias:Findings from the Egger's test (table 8) (SBP: $P=0.205$; DBP: $P=0.611$; Total Cholesterol: $P=0.637$; Triglycerides: $P=.533$; Glucose: $P=0.001$; HbA1C: $P=$ 0.403; and BMI: 0.117; LDL-C: $P=0.066$; HDL-C: $P=0.215)$ supported that there was no publication bias, except within Glucose. The sensitivity analysis for glucose was conducted removing any study did not change the overall results.

\section{Conclusions:}

The Pooled effects based on the meta-analysis found that probiotics improved the health outcomes in patients at risk of cardiovascular disease. This included an overall statistically significant reduction in systolic and diastolic blood pressure, serum cholesterol, serum triglycerides, serum glucose, HbA1C, LDL-C and BMI. It can also be noted there was an overall increase in HDL-C although it is not statistically significant. All outcomes demonstrated a statistically significant reduction in cardiovascular risk factors except HDLC. These findings are highly relevant in patients at risk of cardiovascular disease, with polypharmacy becoming an increasing issue in global health [65]. The capacity to reduce cardiovascular risk factors in conjunction of prescription of pharmaceuticals indicates a significant advance in the field of the human microbiome. Our results are consistent with previously published reviews regarding the effects of probiotics in reducing blood pressure [66], cholesterol [67], serum triglycerides [68][69], serum glucose [70], HbA1C [71] and BMI [72]. Despite correlations these previous studies focused on mono-morbid patient groups rather than a whole society at risk of cardiovascular disease with comorbidities or measured only one outcome variable. None of these studies provided subgroup analysis on our key variables. Our studies included RCT's focusing on adults at risk of cardiovascular disease with comorbidities (diabetes, dyslipidaemia, metabolic syndrome, hypercholesterolaemia, hypertension).

\section{Effects of Probiotics on BP, TC, LDL-C, HDL-C TAG, Glucose, HbAIC and BMI:}


Subgroup analyses revealed the beneficial effects of probiotics may be related to patient morbidity. Diabetic patients displayed the greatest reduction in blood pressure, fasting glucose and triglycerides out of all of the health groups. With a $5.82 \mathrm{mmHg}$ reduction in SBP $(P=0.02)$ and a $3.81 \mathrm{mmHg}$ reduction in DBP $(P<0.001)$. Similarly fasting glucose displayed the most significant reduction in diabetics with $12.94 \mathrm{mg} / \mathrm{dL}(P<0.001)$. Triglycerides and HDL-C also demonstrated the most beneficial effects in diabetic patients with a $14.17 \mathrm{mg} / \mathrm{dL}(P=0.02)$ reduction and $2.03 \mathrm{mg} / \mathrm{dL}(P=0.01)$ mean difference between the intervention and control group.

Outcome variables further indicated analyses may be related to morbidity with hypercholesterolaemic patients displaying the greatest reduction in total cholesterol (16.54 $\mathrm{mg} / \mathrm{dL}, P<0.001)$ and LDL-C $(-20.67 \mathrm{mg} / \mathrm{dL}, P=0.001)$, as did obese patients in BMI $(0.48$ $\left.\mathrm{kg} / \mathrm{m}^{2}, P=0.001\right)$. These results may be explained by the inherent association between these morbidities and the outcome variable, given each patient subgroup showed the most significant reduction in the variable that was most related to their condition. This is a potential form of selection bias [73], whereby it can be expected that each of these subgroups would have a correlation with a given outcome measure.

Probiotics in Yogurt form demonstrated the most significant reductions in the cardiovascular risk factors of total cholesterol $(-9.48 \mathrm{mg} / \mathrm{dL})$, fasting glucose $(-12.88 \mathrm{mg} / \mathrm{dL}), \mathrm{HbA} 1 \mathrm{C}(-$ $0.55 \%)$ and LDL-C $(-18.06 \mathrm{mg} / \mathrm{dL})$; reductions in blood pressure were also observed. Probiotics within the 'other forms' category (Kefir and powder) demonstrated a significant reduction in BMI $\left(-0.5 \mathrm{~kg} / \mathrm{m}^{2}\right)$. One mechanism for explaining this characteristic, is the greater diversity of probiotic species found in kefir and their capacity to stimulate gastric emptying [74]. As such studies have shown a correlation between probiotic strain diversity and gastric motility [75], hence reducing the time for absorption and digestion.

Studies with greater proportions of female patients indicated more significant reductions in outcome measures, specifically; total cholesterol $(-5.59 \mathrm{mg} / \mathrm{dL}, P=0.002)$, fasting glucose ($5.63 \mathrm{mg} / \mathrm{dL}, P=0.001), \mathrm{HbA} 1 \mathrm{C}(-0.18 \%, P=0.007), \mathrm{LDL}-\mathrm{C}(-9.87 \mathrm{mg} / \mathrm{dL}, P=0.001)$, and BMI $\left(-0.35 \mathrm{~kg} / \mathrm{m}^{2}, P=0.001\right)$. One explanation for this is the relationship between the oestrogen-gut microbiome axis, whereby women are at greater risk of microbiota decline [78], thus providing a physiological template for microbiota correction and reduction in CVD risk factors.

Longer treatment duration ( $>1.5$ months) was favoured holistically within the outcome of blood pressure, with reductions of $-2.38 \mathrm{mmHg}$ in SBP $(P=0.04)$ and $-1.98 \mathrm{mmHg}$ in DBP $(P=0.01)$. Reduction over extended period of time could be expected, as resting blood pressure have been shown to require long-term lifestyle intervention [76].

Shorter treatment duration $(<1.5$ months) was statistically favoured for reduction in total cholesterol (-11.61 mg/dL, $P<0.001)$, LDL-C $(-14.01 \mathrm{mg} / \mathrm{dL}, P=0.001)$, fasting glucose ($16.15 \mathrm{mg} / \mathrm{dL}, P=0.003)$ and $\mathrm{HbA1C}(-0.5 \%, P=0.009)$

One mechanism for this can be explained by initial increase in gastric motility providing the majority of the effect in total cholesterol reduction [77] by a reduced absorption time, this may have residual effects with metabolism.

Subgroup analyses revealed higher treatment doses $\left(>1 \times 10^{9} \mathrm{CFU}\right)$ were more effective in reducing BMI $\left(0.41 \mathrm{~kg} / \mathrm{m}^{2}, P=0.001\right)$, total cholesterol $(6.38 \mathrm{mg} / \mathrm{dL}, P<0.001), \mathrm{HbA} 1 \mathrm{C}$ $(12 \%, P=0.06)$, and fasting glucose $(16.15 \mathrm{mg} / \mathrm{dL}, P=0.001)$ respectively. It can also be 
said, results were trending towards higher treatment doses in triglycerides outcome groups for greater effect.

Strengths, Limitations and Implications: Our review used a thorough and comprehensive search strategy in identifying and assessing each article's quality for inclusion within the meta-analysis. Reviewer bias was minimised through individual and independent screening of potential articles before collaboration for final inclusion. One strength of this metaanalysis was the use of broad search terms to allow for manual inclusion of all relevant articles, maximising the power of the study. All articles included were RCT's and from the last 30 years, providing a relevant and up-to date review. Any missing data from studies prompted contacting of authors, and thus all possible data was included in this meta-analysis at the time of publication. All studies included adults at risk of cardiovascular disease and therefore the effect of probiotics could be assessed. Subgroup analysis provided statistical insight into formulations, dosages and patient groups most susceptible to treatment. This meta-analysis strengthens prior published findings. For example, a meta-analysis [27], which included 15 studies (788 adults with CVD risk) reported statistically significant reduction in cholesterol and BMI, whereas our study had 34 RCT's ( $n=2,177$ adults with CVD risk) which found probiotics significantly reduce the risk of cardiovascular disease in high risk patient groups. A limitation of this study is the inconsistent use of strain types among studies, disallowing for accurate assessment of individual strain efficacy. However, this allowed for cross analysis of the relationship between strain

number and therapeutic efficacy. Another limitation of this study is the small population samples within each study, these was primarily mitigated through inclusion of all available studies, however, a larger sample size could improve the statistical power of the study. These limitations are primarily due to a lack of literature available. Further RCT's observing the effects of single and multiple strain use on patients with cardiovascular risk factors are required to further clarify findings.

\section{Acknowledgments:}

Authorship: The authors' responsibilities were as follows - AD: Conceptualised and designed the study, developed search strategy, collected and extracted the data, interpreted the data, all table formulation, referencing, PEDro table development, article drafting, edited and submitted manuscript, critically revised the article - KR: data extraction - AY: data collection, data extraction, formulated table 2 - MQ: data extraction, referencing, table formulation, edited manuscript - HR: data extraction, formulated table 2 - DW: PEDro table development - TC: data extraction, referencing, subgroup table formatting, edited. DR: data extraction - CC: statistical analysis and subgroup calculations - JS: Designed the study, statistical analysis and subgroup calculations.

\section{Compliance with Ethics Guidelines:}

Conflict of Interest: The authors declare no conflicts of interest relevant to this manuscript.

Human and Animal Rights and Informed Consent: This article does not contain any studies with human or animal subjects performed by any of the authors. 
Figure 2. Forest plots of the effects of probiotics on Systolic Blood Pressure (A), Diastolic blood Pressure (B), Cholesterol (C), Triglycerides (D), Serum Glucose (E), HbA1C (F), BMI (G), LDL-C (H), HDL-C (I).

A

Effect of Probiotics on SBP

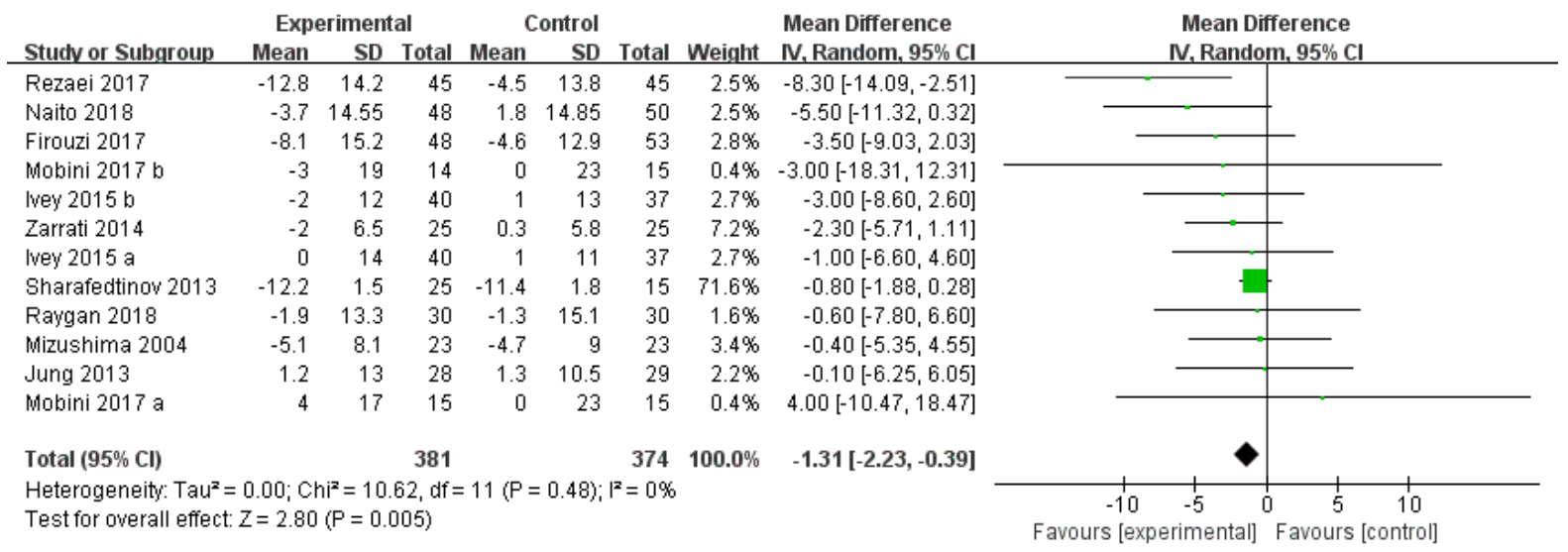

B

Effect of Probiotics DBP

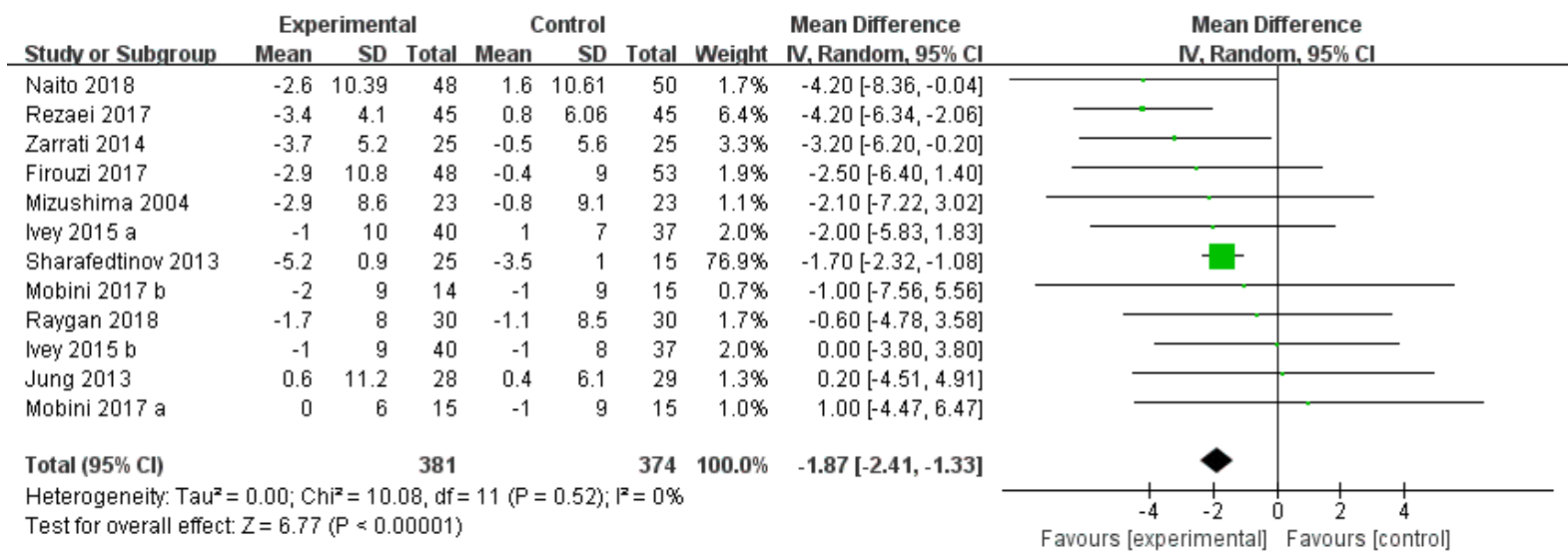




\begin{tabular}{|c|c|c|c|c|c|c|c|c|c|c|c|}
\hline \multirow[b]{2}{*}{ Studv or Subgroup } & \multicolumn{3}{|c|}{ Experimental } & \multicolumn{2}{|c|}{ Control } & \multirow[b]{2}{*}{ Total } & \multirow[b]{2}{*}{ Weight } & \multirow{2}{*}{$\begin{array}{l}\text { Mean Difference } \\
\text { IV, Random, } 95 \% \mathrm{Cl}\end{array}$} & \multirow{2}{*}{\multicolumn{2}{|c|}{$\begin{array}{c}\text { Mean Difference } \\
\text { IV, Random, } 95 \% \mathrm{Cl}\end{array}$}} & \\
\hline & Mean & SD & Total & Mean & SD & & & & & & \\
\hline Cavallini 2016 a & -28.94 & 17.37 & 17 & -3.86 & 29.4 & 15 & $2.1 \%$ & $-25.08[-42.10,-8.06]$ & & & \\
\hline Rezaei 2017 & -18.26 & 40.5 & 45 & 2.2 & 38.6 & 45 & $2.2 \%$ & $-20.46[-36.81,-4.11]$ & & & \\
\hline Shekeri $2014 \mathrm{~b}$ & -16 & 30.5 & 24 & -0.5 & 35.3 & 24 & $1.7 \%$ & $-15.50[-34.16,3.16]$ & & & \\
\hline Jones 2012 & -27.26 & 34.5 & 56 & -12.84 & 30.46 & 58 & $4.2 \%$ & $-14.42[-26.38,-2.46]$ & & & \\
\hline Mafi 2018 & -18.4 & 31.8 & 30 & -5.4 & 32.3 & 30 & $2.3 \%$ & $-13.00[-29.22,3.22]$ & & & \\
\hline Mizushima 2004 & -3.9 & 19 & 23 & 7.36 & 34 & 23 & $2.4 \%$ & $-11.26[-27.18,4.66]$ & & & \\
\hline Szulinska 2018 a & -16 & 29.24 & 23 & -5.52 & 27.52 & 24 & $2.3 \%$ & $-10.48[-26.73,5.77]$ & & & \\
\hline Firouzi 2017 & -2.32 & 36.28 & 48 & 7.72 & 31.27 & 53 & $3.4 \%$ & $-10.04[-23.31,3.23]$ & & - & \\
\hline Shekeri 2014 a & -10.3 & 38.9 & 24 & -0.5 & 35.3 & 24 & $1.3 \%$ & $-9.80[-30.82,11.22]$ & & & \\
\hline Sharafedtinov 2013 & -47.9 & 46.3 & 25 & -38.19 & 33.6 & 15 & $1.0 \%$ & $-9.71[-34.58,15.16]$ & & & \\
\hline Cavallini 2016 b & -13.51 & 33.2 & 17 & -3.86 & 29.4 & 15 & $1.3 \%$ & $-9.65[-31.34,12.04]$ & & & \\
\hline Asemi 2013 & 4.9 & 38.45 & 27 & 13.2 & 34.29 & 27 & $1.6 \%$ & $-8.30[-27.73,11.13]$ & & & \\
\hline Raygan 2018 & -5 & 27.2 & 30 & 3 & 34 & 30 & $2.5 \%$ & $-8.00[-23.58,7.58]$ & & & \\
\hline Mobini 2017 a & -3.86 & 34.74 & 15 & 3.86 & 34.74 & 15 & $1.0 \%$ & $-7.72[-32.58,17.14]$ & & & \\
\hline Higashikawa 2016 b & -10.8 & 9 & 21 & -3.1 & 10.4 & 20 & $16.7 \%$ & $-7.70[-13.67,-1.73]$ & & & \\
\hline Naito 2018 & 2.6 & 27.02 & 48 & 10.1 & 30.41 & 50 & $4.6 \%$ & $-7.50[-18.88,3.88]$ & & & \\
\hline Abbasi 2018 & -12.4 & 19.7 & 20 & -4.9 & 22.7 & 20 & $3.4 \%$ & $-7.50[-20.67,5.67]$ & & & \\
\hline Szulinska 2018 b & -10.77 & 22.63 & 24 & -5.52 & 27.52 & 24 & $2.9 \%$ & $-5.25[-19.50,9.00]$ & & & \\
\hline lvey 2015 a & -5.4 & 34 & 40 & -0.81 & 51.4 & 37 & $1.5 \%$ & $-4.59[-24.22,15.04]$ & & & \\
\hline Mobini $2017 \mathrm{~b}$ & 0 & 38.6 & 14 & 3.86 & 34.74 & 15 & $0.8 \%$ & $-3.86[-30.65,22.93]$ & & & \\
\hline Ostadrahimi 2015 & -11.79 & 61.03 & 30 & -8.6 & 54.85 & 30 & $0.7 \%$ & $-3.19[-32.55,26.17]$ & & & \\
\hline Madjd 2016 & -13.9 & 22.77 & 44 & -11.58 & 23.55 & 45 & $6.4 \%$ & $-2.32[-11.94,7.30]$ & & & \\
\hline Tajabadi-Ebrahimi 2017 & 4.6 & 28.4 & 30 & 6.7 & 29.6 & 30 & $2.8 \%$ & $-2.10[-16.78,12.58]$ & & & \\
\hline lvey 2015 b & -1.5 & 42.5 & 40 & -0.4 & 42.2 & 37 & $1.7 \%$ & $-1.10[-20.03,17.83]$ & & & \\
\hline Higashikawa 2016 a & -4.1 & 7 & 21 & -3.1 & 10.4 & 20 & $20.0 \%$ & $-1.00[-6.45,4.45]$ & & & \\
\hline Ebrahimi 2017 & -1.12 & 26.47 & 35 & -3 & 28.63 & 35 & $3.6 \%$ & $1.88[-11.04,14.80]$ & & & \\
\hline Gomes 2017 & -5.404 & 31.652 & 21 & -8.106 & 45.162 & 22 & $1.1 \%$ & $2.70[-20.52,25.93]$ & & & \\
\hline Razmpoosh 2019 & 2.1 & 35.2 & 30 & -1.3 & 38.5 & 30 & $1.7 \%$ & $3.40[-15.27,22.07]$ & & & \\
\hline Inoue 2003 & 3.2 & 24.18 & 18 & -0.5 & 42.06 & 17 & $1.1 \%$ & $3.70[-19.20,26.60]$ & & & \\
\hline Jung 2013 & 5 & 35.8 & 28 & 1.2 & 33.9 & 29 & $1.8 \%$ & $3.80[-14.31,21.91]$ & & & \\
\hline Total (95\% Cl) & & & 868 & & & 859 & $100.0 \%$ & $-6.05[-8.49,-3.61]$ & & & \\
\hline $\begin{array}{l}\text { Heterogeneity: } \operatorname{Tau}^{2}=0.00 \\
\text { Test for overall effect: } Z=\end{array}$ & $\begin{array}{l}C h i^{2}=2 \\
86(P<C\end{array}$ & $\begin{array}{l}2.57, \mathrm{df}= \\
.00001)\end{array}$ & $9(\mathrm{P}=$ & $=0.80)$ & $=0 \%$ & & & & -20 & 10 & 20 \\
\hline
\end{tabular}

D

\section{Effect of Probiotics on Triglycerides}

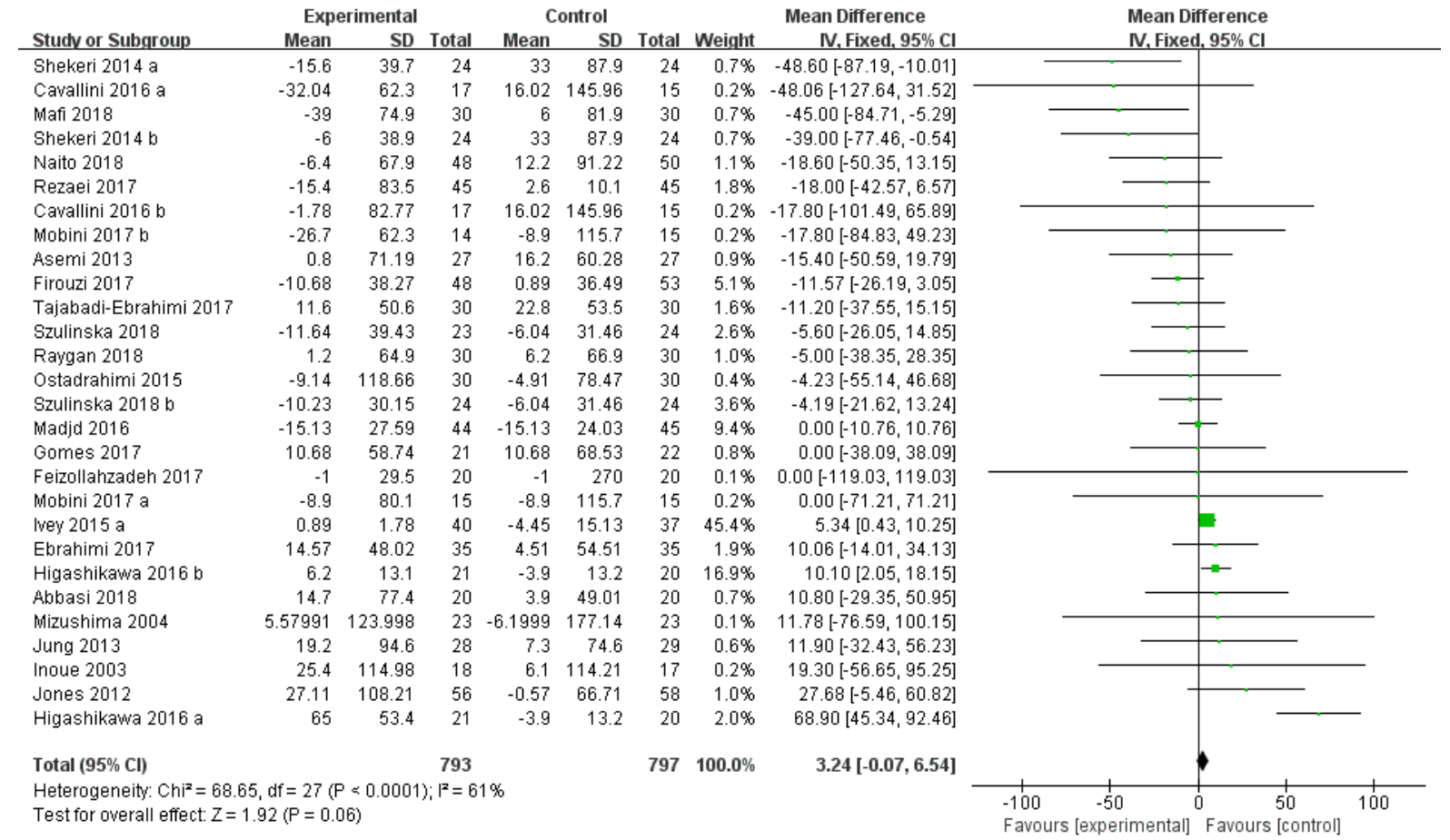




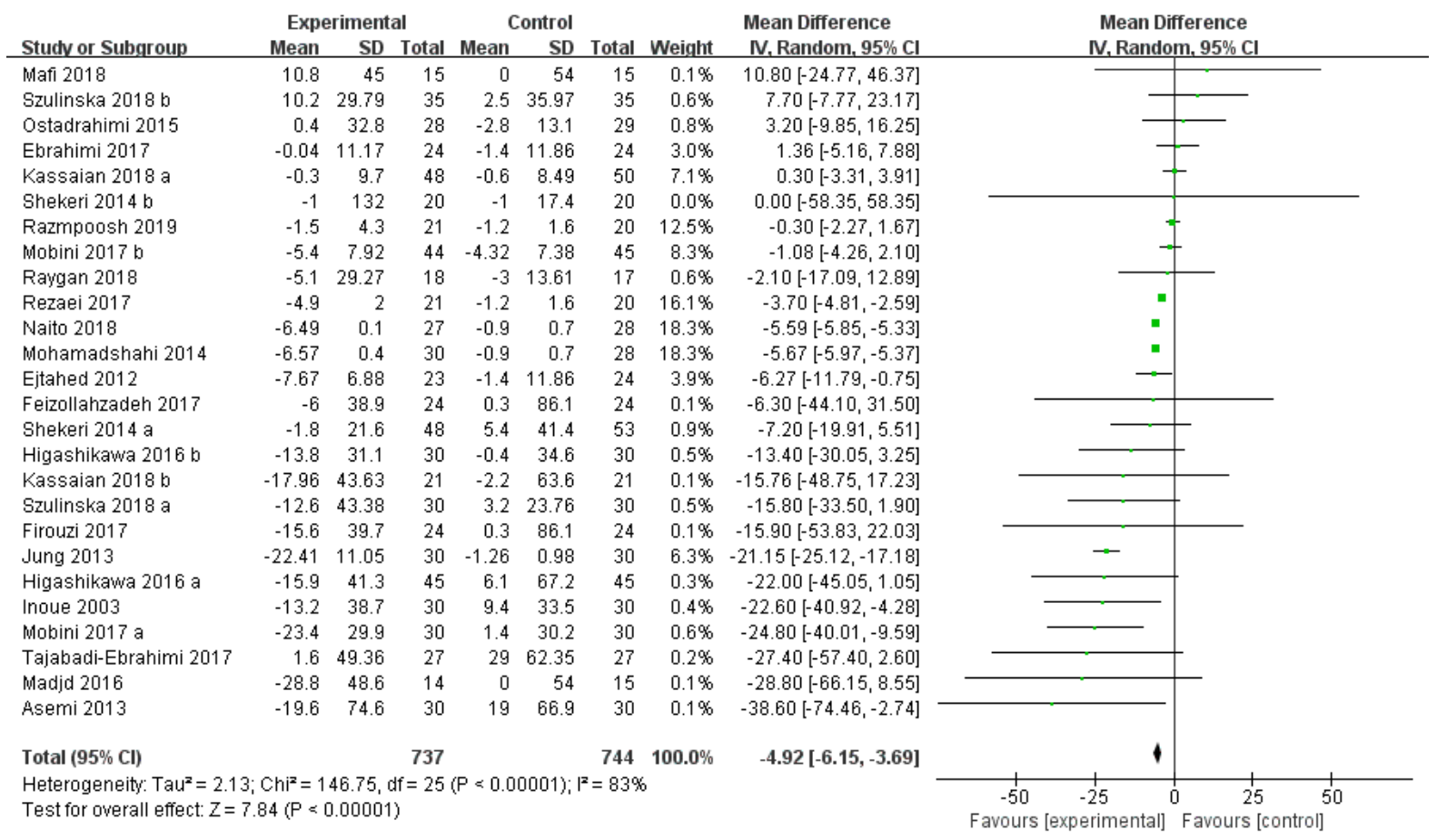

F

\begin{tabular}{lrrrrr} 
& \multicolumn{3}{c}{ Experimental } & \multicolumn{3}{c}{ Control } \\
Studv or Subgroup & Mean & SD & Total & Mean & SD \\
\hline Ostadrahimi 2015 & -1.21 & 0.69 & 30 & 0.02 & 0.35 \\
Mohamadshahi 2014 & -1.15 & 1.23 & 21 & -0.24 & 1.58 \\
Mohammadi-Sartang 2014 & -1.15 & 0.45 & 22 & -0.24 & 0.12 \\
Rezaei 2017 & -0.4 & 1.7 & 45 & 0.2 & 0.9 \\
Ejtahed 2012 & -0.12 & 1.24 & 30 & 0.3 & 0.66 \\
Asemi 2013 & -0.03 & 2.13 & 27 & 0.18 & 1.3 \\
Kassaian 2018 a & -0.12 & 0.1 & 27 & 0.08 & 0.1 \\
Firouzi 2017 & -0.14 & 1.4 & 48 & 0.02 & 1.7 \\
Mafi 2018 & -0.1 & 0.4 & 30 & 0 & 0.3 \\
Higashikawa 2016 b & 0.04 & 0.12 & 21 & 0.07 & 0.08 \\
Higashikawa 2016 a & 0.04 & 0.09 & 21 & 0.07 & 0.08 \\
Madjd 2016 & -0.3 & 0.47 & 44 & -0.27 & 0.5 \\
Gomes 2017 & -1.07 & 0.36 & 21 & -1.06 & 0.66 \\
Naito 2018 & -0.05 & 0.35 & 48 & -0.04 & 0.28 \\
Kassaian 2018 b & -0.15 & 0 & 30 & 0.08 & 0.1 \\
Mobini 2017 a & 0 & 0.6 & 15 & 0 & 0.6 \\
Jung 2013 & 0 & 0.3 & 28 & -0.1 & 0.2 \\
Mobini 2017 b & 0.1 & 1 & 14 & 0 & 0.6 \\
Ebrahimi 2017 & 0.3 & 0.46 & 35 & -0.26 & 0.6
\end{tabular}

Total $(95 \% \mathrm{Cl})$ 557

Heterogeneity: $\mathrm{Tau}^{2}=0.05 ; \mathrm{Chi}^{2}=202.97, \mathrm{df}=17(\mathrm{P}<0.00001) ; \mathrm{I}^{2}=92 \%$

Test for overall effect: $Z=2.82(P=0.005)$

\section{Effect of Probiotics on HbA1C}

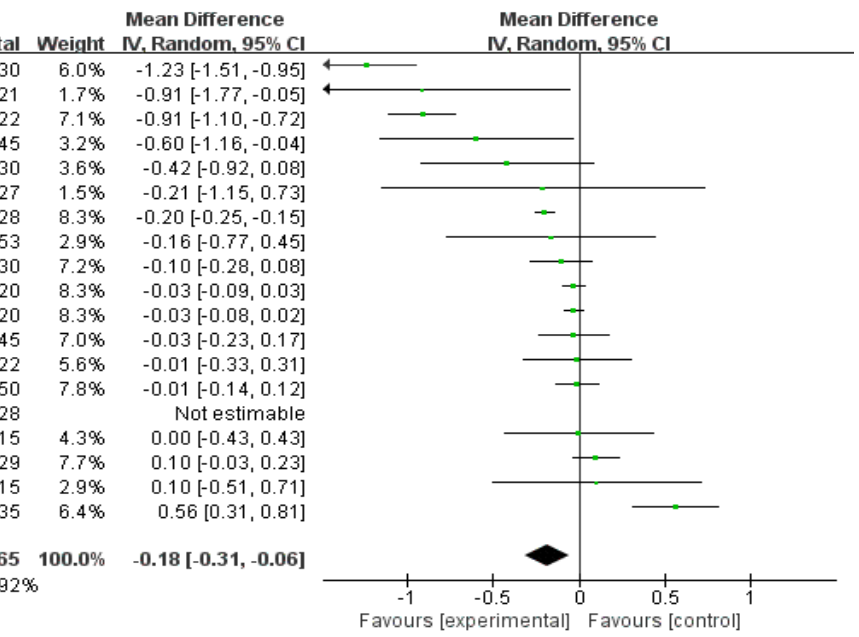




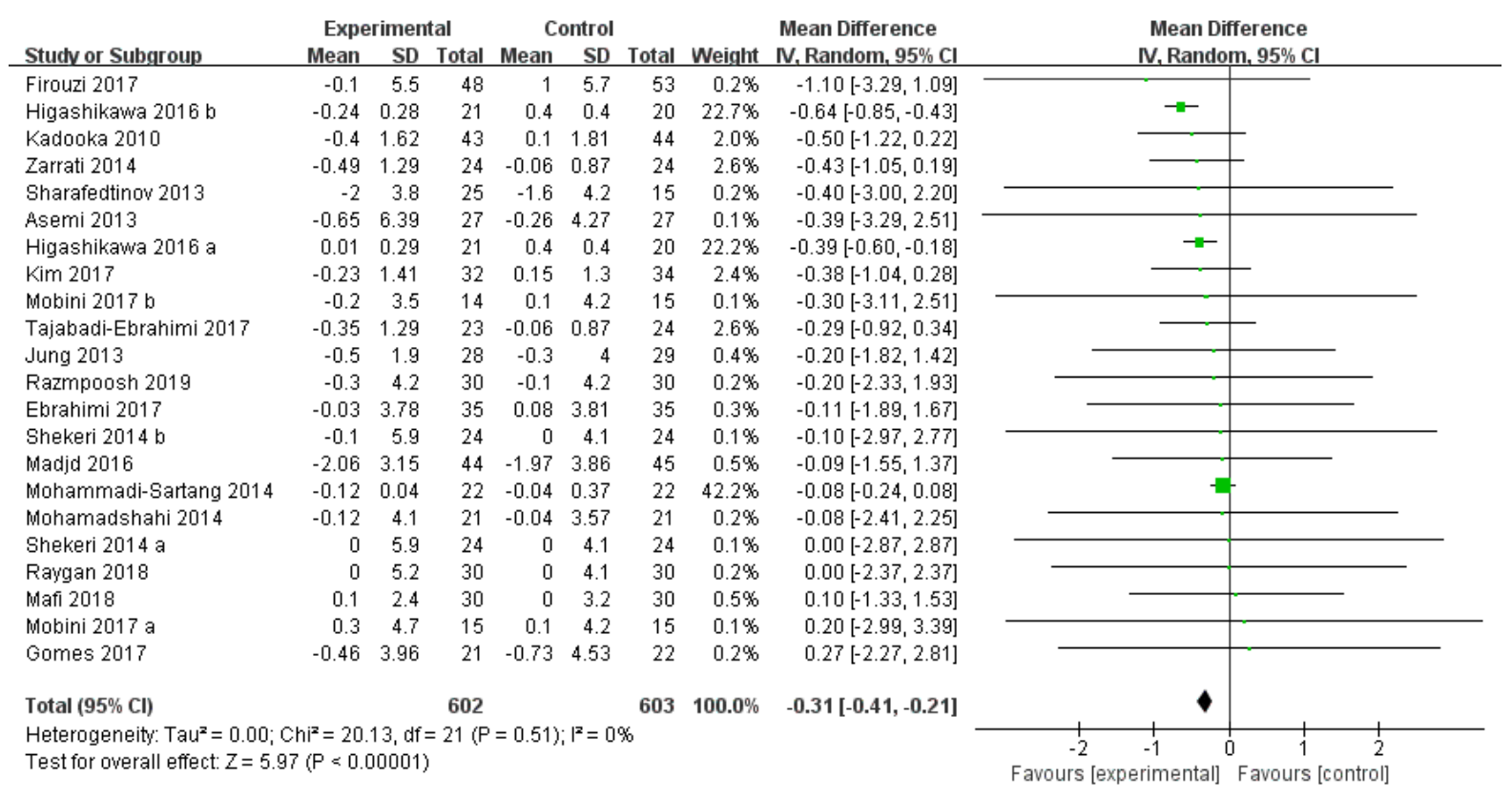

H

Effect of Probiotics on LDL

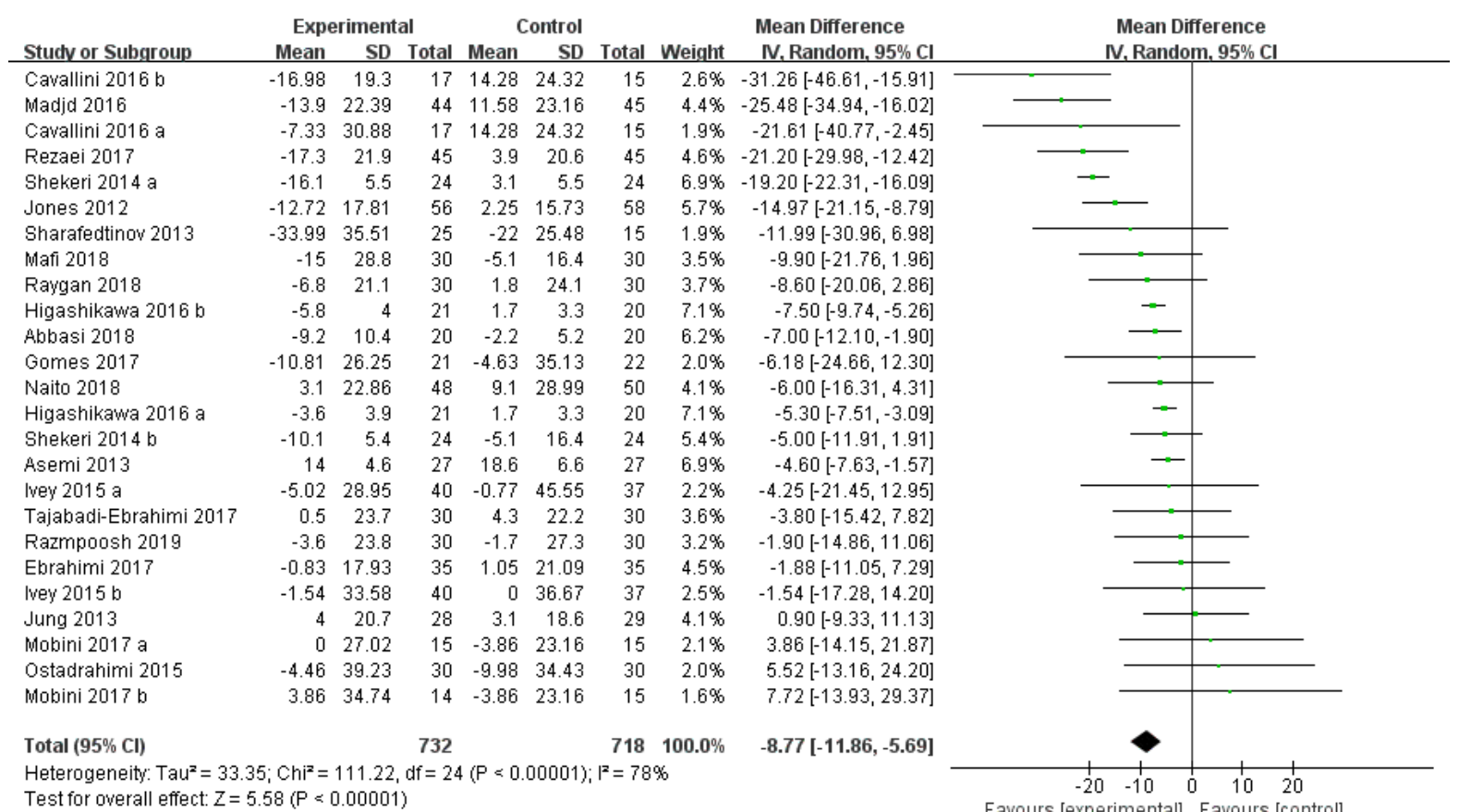

Heterogeneity: $\mathrm{Tau}^{2}=33.35 ; \mathrm{Chi}^{2}=111.22$,
Test for overall effect: $Z=5.58(P<0.00001)$

Favours [experimental] Favours [control] 


\section{I}

\begin{tabular}{lrr} 
& \multicolumn{2}{c}{ Experimenta } \\
Study or Subgroup & Mean & SO \\
\hline Mizushima 2004 & -2.32 & 12.74 \\
Sharafedtinov 2013 & -7.33 & 6.56 \\
Higashikawa 2016 a & -3 & 1.2 \\
Higashikawa 2016 b & -2.9 & 1.5 \\
Ivey 2015 b & -0.772 & 12.74 \\
Raygan 2018 & -1.6 & 7.4 \\
Ostadrahimi 2015 & -1.36 & 13.3 \\
Ivey 2015 a & -0.772 & 13.12 \\
Gomes 2017 & -1.93 & 82.99 \\
Mobini 2017 o & 0 & 11.58 \\
Asemi 2013 & 0 & 2.3 \\
Mobini 2017 a & 0 & 15.44 \\
Naito 2018 & 1.9 & 12.47 \\
Janes 2012 & -1.75 & 24.17 \\
Abbasi 2018 & 1.11 & 2.8 \\
Madjd 2016 & 2.7 & 7.33 \\
Rezaei 2017 & 0.62 & 6.6 \\
Ebrahimi 2017 & 0.54 & 5.84 \\
Razmpoosh 2019 & 2.1 & 10.8 \\
Jung 2013 & -0.7 & 9.9 \\
Shekeri 2014 a & 1.2 & 1.4 \\
Tajabadi-Ebrahimi 2017 & 1.8 & 5.7 \\
Shekeri 2014 b & 2.2 & 1.4 \\
Mafi 2018 & 4.4 & 4.9 \\
Cavallini 2016 b & -5.79 & 8.49 \\
Cavallini 2016 a & -3.86 & 6.95
\end{tabular}

Effect of Probiotics on HDL

Control Mean Difference

IV. Random, $95 \% \mathrm{Cl}$

$-6.18[-14,36,2,00]$

$-1.80[-2.50,-1,10]$

$-1.70[-2.50,-0.90]$

$-1.54[-7.51,4.43]$

$-1,40[-4,85,2,05]$

$-1.09[-7.37,5.19]$

$-0,77[-6,46,4.92]$

$-77[-59,49,57.95]$

$0.00[-8.43,8.43]$

$0.00[-1.20,1.20]$

$0.00[-9.77,9.77]$

$0.10[-4.49,4.69]$

$0.14[-8.12,8.40]$

$0.21[-1.49,1.91]$

$0.38(-2,51,3.27]$

$0.52[-3.30 .4 .34]$

$1.65[-1.15,4.45]$

$2.20[-2,39,6.79]$

$3,20[-1,94,8.34]$

$3.30[2.51,4.09]$

$4.00[1.04,6.96]$

$4.30[3.51,5.09]$

$5.80[3,65,7.95]$

$8.49[0,04,16,94]$

$10.42[2.29,18.55]$

$1.05[-0.33,2.43]$

Total $(95 \% \mathrm{Cl})$

755

$741 \quad 100.0 \%$

Heterogeneity; Tau $^{2}=780 ;$ Chi $^{2}=249,24, \mathrm{df}=25(\mathrm{P}<0,00001) ; \mathrm{P}=90 \%$

Test for overall effect: $Z=1.49(P=0.14)$
Mean Difference

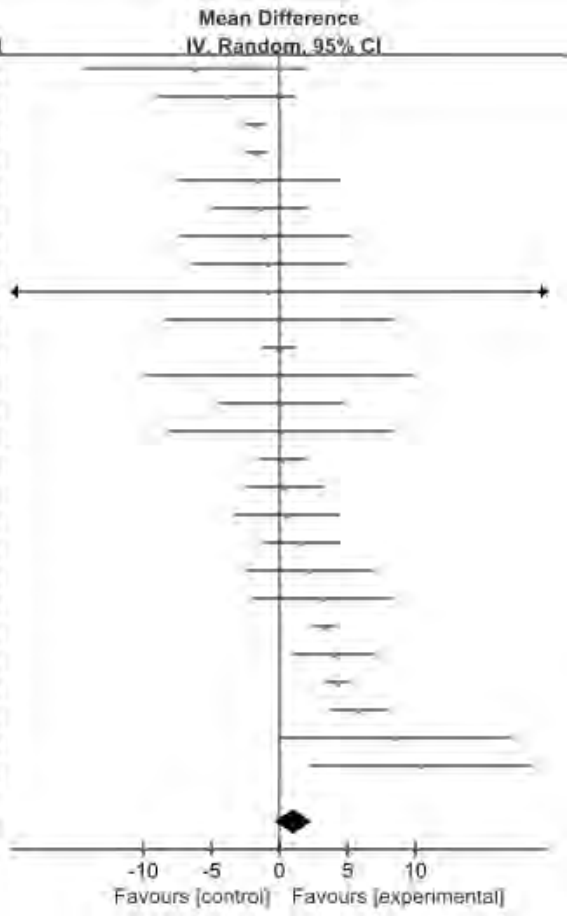




\begin{tabular}{|c|c|c|c|c|c|c|c|c|c|c|c|c|}
\hline Trial & $\begin{array}{c}\text { Specified } \\
\text { Eligibility } \\
\text { Criteria }\end{array}$ & $\begin{array}{l}\text { Random } \\
\text { Allocation }\end{array}$ & $\begin{array}{c}\text { Allocation } \\
\text { Concealment }\end{array}$ & $\begin{array}{c}\text { Blinding } \\
\text { of } \\
\text { Subjects }\end{array}$ & $\begin{array}{c}\text { Blinding } \\
\text { of } \\
\text { Assessors }\end{array}$ & $\begin{array}{l}\text { Blinding of } \\
\text { Researchers }\end{array}$ & $\begin{array}{c}\text { Similar } \\
\text { at } \\
\text { baseline }\end{array}$ & $\begin{array}{c}\text { Key outcome } \\
\text { measurement } \\
85 \%\end{array}$ & $\begin{array}{c}\text { Intention } \\
\text { to treat }\end{array}$ & $\begin{array}{c}\text { Between } \\
\text { group } \\
\text { comparison }\end{array}$ & $\begin{array}{l}\text { Measure of } \\
\text { variability }\end{array}$ & $\begin{array}{l}\text { Total } \\
\text { score }\end{array}$ \\
\hline Abbasi et al. (2018) [31]** & $\mathrm{X}$ & $\mathrm{X}$ & $\mathrm{X}$ & $\mathrm{X}$ & $\mathrm{X}$ & $\mathrm{X}$ & $\mathrm{X}$ & $\mathrm{X}$ & - & $\mathrm{X}$ & $\mathrm{X}$ & $10 / 11$ \\
\hline Agerholm-Larsen et al (2000) [32] & $\mathrm{X}$ & $\mathrm{X}$ & - & $\mathrm{X}$ & $\mathrm{X}$ & - & - & $\mathrm{X}$ & - & $\mathrm{X}$ & $\mathrm{X}$ & $7 / 11$ \\
\hline Asemi et al. (2013) [33] & $\mathrm{X}$ & $\mathrm{X}$ & - & $\mathrm{X}$ & $\mathrm{X}$ & - & $\mathrm{X}$ & $\mathrm{X}$ & - & $\mathrm{X}$ & $\mathrm{X}$ & $8 / 11$ \\
\hline Cavallini et al. (2016) [34] & $X$ & $\mathrm{X}$ & $\mathrm{X}$ & $\mathrm{X}$ & $\mathrm{X}$ & $\mathrm{X}$ & $\mathrm{X}$ & $\mathrm{X}$ & - & $\mathrm{X}$ & $\mathrm{X}$ & $10 / 11$ \\
\hline Ebrahimi et al. (2017) [35] & $\mathrm{X}$ & $\mathrm{X}$ & $\mathrm{X}$ & $\mathrm{X}$ & $\mathrm{X}$ & $\mathrm{X}$ & $\mathrm{X}$ & $\mathrm{X}$ & - & $\mathrm{X}$ & $\mathrm{X}$ & $10 / 11$ \\
\hline Ejtahed et al. (2012) [36] & $\mathrm{X}$ & $\mathrm{X}$ & $\mathrm{X}$ & $\mathrm{X}$ & $\mathrm{X}$ & $\mathrm{X}$ & $\mathrm{X}$ & $\mathrm{X}$ & - & $\mathrm{X}$ & $\mathrm{X}$ & $10 / 11$ \\
\hline Feizollahzadeh et al. (2017) [37] * & $\mathrm{X}$ & $\mathrm{X}$ & - & $\mathrm{X}$ & $\mathrm{X}$ & - & $\mathrm{X}$ & - & - & $\mathrm{X}$ & $\mathrm{X}$ & $7 / 11$ \\
\hline Firouzi et al. (2017) [38]** & $\mathrm{X}$ & $\mathrm{X}$ & $\mathrm{X}$ & $\mathrm{X}$ & $\mathrm{X}$ & $\mathrm{X}$ & $\mathrm{X}$ & - & $\mathrm{X}$ & $\mathrm{X}$ & $\mathrm{X}$ & $10 / 11$ \\
\hline Gomes et al. (2017) [39] & $\mathrm{X}$ & $\mathrm{X}$ & $\mathrm{X}$ & $\mathrm{X}$ & $\mathrm{X}$ & $\mathrm{X}$ & $\mathrm{X}$ & - & $\mathrm{X}$ & $\mathrm{X}$ & $\mathrm{X}$ & $10 / 11$ \\
\hline Hata et al. (1996) [40] & $\mathrm{X}$ & $\mathrm{X}$ & - & $\mathrm{X}$ & - & - & $\mathrm{X}$ & - & - & $\mathrm{X}$ & $\mathrm{X}$ & $6 / 11$ \\
\hline Higashikawa et al. (2016) [41] & $\mathrm{X}$ & $\mathrm{X}$ & $\mathrm{X}$ & $\mathrm{X}$ & $\mathrm{X}$ & $\mathrm{X}$ & $\mathrm{X}$ & $\mathrm{X}$ & $\mathrm{X}$ & $\mathrm{X}$ & $\mathrm{X}$ & $11 / 11$ \\
\hline Inoue et al. (2003) [42] & $\mathrm{X}$ & $\mathrm{X}$ & - & $\mathrm{X}$ & - & - & $\mathrm{X}$ & $\mathrm{X}$ & - & $\mathrm{X}$ & $\mathrm{X}$ & $7 / 11$ \\
\hline Ivey et al. (2015) [43] & $X$ & $\mathrm{X}$ & - & - & - & - & $\mathrm{X}$ & $\mathrm{X}$ & - & $\mathrm{X}$ & $\mathrm{X}$ & $6 / 11$ \\
\hline Jones et al. (2012) [44] & $\mathrm{X}$ & $\mathrm{X}$ & - & $\mathrm{X}$ & $\mathrm{X}$ & - & $\mathrm{X}$ & $\mathrm{X}$ & $\mathrm{X}$ & $\mathrm{X}$ & $\mathrm{X}$ & $9 / 11$ \\
\hline Jung et al. (2013) [45] & $\mathrm{X}$ & $\mathrm{X}$ & $\mathrm{X}$ & $\mathrm{X}$ & $\mathrm{X}$ & - & $\mathrm{X}$ & - & $\mathrm{X}$ & $\mathrm{X}$ & $\mathrm{X}$ & $9 / 11$ \\
\hline Kadooka et al. (2010) [46] & $\mathrm{X}$ & $\mathrm{X}$ & - & $\mathrm{X}$ & $\mathrm{X}$ & - & $\mathrm{X}$ & $\mathrm{X}$ & - & $\mathrm{X}$ & $\mathrm{X}$ & $8 / 11$ \\
\hline Kassaian et al. (2018) [47] * & $\mathrm{X}$ & $\mathrm{X}$ & $\mathrm{X}$ & $\mathrm{X}$ & $\mathrm{X}$ & $\mathrm{X}$ & $\mathrm{X}$ & - & - & $\mathrm{X}$ & $\mathrm{X}$ & $9 / 11$ \\
\hline Kim et al. (2017) [48]** & $\mathrm{X}$ & $\mathrm{X}$ & $\mathrm{X}$ & $\mathrm{X}$ & $\mathrm{X}$ & - & $\mathrm{X}$ & $\mathrm{X}$ & - & $\mathrm{X}$ & $\mathrm{X}$ & $9 / 11$ \\
\hline Madjd et al. (2016) [49] & $\mathrm{X}$ & $\mathrm{X}$ & $\mathrm{X}$ & $\mathrm{X}$ & - & - & $\mathrm{X}$ & $X$ & $\mathrm{X}$ & $\mathrm{X}$ & $\mathrm{X}$ & $9 / 11$ \\
\hline Mafi et al. (2018) [50]* & $\mathrm{X}$ & $\mathrm{X}$ & $\mathrm{X}$ & $\mathrm{X}$ & $\mathrm{X}$ & - & $\mathrm{X}$ & $\mathrm{X}$ & $\mathrm{X}$ & $\mathrm{X}$ & $\mathrm{X}$ & $10 / 11$ \\
\hline Mizushima et al. (2004) [51] & $\mathrm{X}$ & $\mathrm{X}$ & - & $\mathrm{X}$ & $\mathrm{X}$ & - & $\mathrm{X}$ & $\mathrm{X}$ & - & $\mathrm{X}$ & $\mathrm{X}$ & $8 / 11$ \\
\hline Mobini et al. (2017) [52]* & $\mathrm{X}$ & $\mathrm{X}$ & - & $\mathrm{X}$ & $\mathrm{X}$ & $\mathrm{X}$ & $\mathrm{X}$ & $\mathrm{X}$ & - & $\mathrm{X}$ & $\mathrm{X}$ & $9 / 11$ \\
\hline Mohamadshahi et al. (2018) [53] & $\mathrm{X}$ & $\mathrm{X}$ & - & $\mathrm{X}$ & $\mathrm{X}$ & - & $\mathrm{X}$ & $\mathrm{X}$ & - & $\mathrm{X}$ & $\mathrm{X}$ & $8 / 11$ \\
\hline Mohammadi-Sartang et al. (2014) [54] & $\mathrm{X}$ & $\mathrm{X}$ & - & $\mathrm{X}$ & $\mathrm{X}$ & - & $\mathrm{X}$ & $\mathrm{X}$ & - & $\mathrm{X}$ & $\mathrm{X}$ & $8 / 11$ \\
\hline Naito et al. (2018) [55] & $\mathrm{X}$ & $\mathrm{X}$ & $\mathrm{X}$ & $\mathrm{X}$ & $\mathrm{X}$ & $\mathrm{X}$ & $\mathrm{X}$ & $\mathrm{X}$ & - & $\mathrm{X}$ & $\mathrm{X}$ & $10 / 11$ \\
\hline Ostadrahimi et al. (2015) [56] & $\mathrm{X}$ & $\mathrm{X}$ & $\mathrm{X}$ & $\mathrm{X}$ & $\mathrm{X}$ & - & $\mathrm{X}$ & $\mathrm{X}$ & - & $\mathrm{X}$ & $\mathrm{X}$ & $9 / 11$ \\
\hline Raygan et al. (2018) [57] & $\mathrm{X}$ & $\mathrm{X}$ & $\mathrm{X}$ & $\mathrm{X}$ & $\mathrm{X}$ & $\mathrm{X}$ & $\mathrm{X}$ & $\mathrm{X}$ & $\mathrm{X}$ & $\mathrm{X}$ & $\mathrm{X}$ & $11 / 11$ \\
\hline Razmpoosh et al. (2019) [58]* & $\mathrm{X}$ & $\mathrm{X}$ & $\mathrm{X}$ & $\mathrm{X}$ & $\mathrm{X}$ & $\mathrm{X}$ & - & $\mathrm{X}$ & - & $\mathrm{X}$ & $\mathrm{X}$ & $9 / 11$ \\
\hline Rezaei et al. (2017) [59]** & $\mathrm{X}$ & $\mathrm{X}$ & $\mathrm{X}$ & $\mathrm{X}$ & $\mathrm{X}$ & $\mathrm{X}$ & - & $\mathrm{X}$ & - & $\mathrm{X}$ & $\mathrm{X}$ & $9 / 11$ \\
\hline Sharafedtinov et al. (2013) [60] & $\mathrm{X}$ & $\mathrm{X}$ & $\mathrm{X}$ & $\mathrm{X}$ & $\mathrm{X}$ & - & - & - & - & $\mathrm{X}$ & $\mathrm{X}$ & $7 / 11$ \\
\hline Shakeri et al. (2014) [61] & $\mathrm{X}$ & $\mathrm{X}$ & - & $\mathrm{X}$ & $\mathrm{X}$ & - & $\mathrm{X}$ & $\mathrm{X}$ & $\mathrm{X}$ & $\mathrm{X}$ & $\mathrm{X}$ & $9 / 11$ \\
\hline Szulinska et al. (2018) [62] * & $\mathrm{X}$ & $\mathrm{X}$ & $\mathrm{X}$ & $\mathrm{X}$ & $\mathrm{X}$ & $\mathrm{X}$ & - & $\mathrm{X}$ & - & $\mathrm{X}$ & $\mathrm{X}$ & $9 / 11$ \\
\hline Tajabadi-Ebrahimi et al. (2017) [63] ** & $\mathrm{X}$ & $\mathrm{X}$ & $\mathrm{X}$ & $\mathrm{X}$ & $\mathrm{X}$ & $\mathrm{X}$ & $\mathrm{X}$ & $\mathrm{X}$ & $\mathrm{X}$ & $\mathrm{X}$ & $\mathrm{X}$ & $11 / 11$ \\
\hline Zarrati et al. (2014) [64] & $\mathrm{X}$ & $\mathrm{X}$ & $\mathrm{X}$ & $\mathrm{X}$ & $\mathrm{X}$ & - & $\mathrm{X}$ & $\mathrm{X}$ & - & $\mathrm{X}$ & $\mathrm{X}$ & $9 / 11$ \\
\hline
\end{tabular}

$(X)=$ Characteristic within study, $(-)=$ Characteristic absent within study. 


\begin{tabular}{|c|c|c|c|c|c|c|c|c|c|c|c|}
\hline $\begin{array}{l}\text { Study (year) } \\
\text { (ref.) }\end{array}$ & $\begin{array}{l}\text { Design; } \\
\text { location }\end{array}$ & $\begin{array}{l}\text { Participants } \\
\text { at beginning } \\
\quad n(\mathbf{P} / \mathbf{C})\end{array}$ & $\begin{array}{l}\text { Attrition rate } n \\
(\%)\end{array}$ & Comorbidities & $\begin{array}{c}\begin{array}{c}\text { Age, } \mathbf{P} / \mathbf{C}, \\
\text { multiple } \mathbf{P} \\
\text { groups } \\
\text { labelled as (1), } \\
(2)\end{array} \\
\end{array}$ & $\begin{array}{l}\text { Sex, } \boldsymbol{n}(\mathbf{P}, \mathbf{C}) \\
\quad(\mathbf{M} / \mathbf{F})\end{array}$ & Control & Probiotic strain(s) & Dose, CFU/g & $\begin{array}{l}\text { Measured } \\
\text { outcomes }\end{array}$ & Key results \\
\hline $\begin{array}{l}\text { Abbasi et al. } \\
(2018)\end{array}$ & DB; Iran & 44 & $4(9.0)$ & ow & $56.9 / 53.6$ & Not mentioned & Soymilk & Lactobacillus Plantarum A7 & $2 \times 10^{7}$ & Chol, TAG & $\begin{array}{l}\text { Consumption of probiotic soymilk improved LDL and serum } \\
\text { TAG significantly more than conventional soymilk }(P=0.01 \text { and } \\
P=0.007 \text { respectively). }\end{array}$ \\
\hline $\begin{array}{c}\text { Agerholm-Larsen } \\
\text { et al. (2000) }\end{array}$ & DB; Denmark & 36 & $0(.0)$ & оW, ов & $38.6 / 38.3$ & $4 / 12,3 / 7$ & $\begin{array}{c}\text { Calcium lactate } \\
\text { placebo }\end{array}$ & $\begin{array}{l}\text { Streptococcus thermophilus, } \\
\text { Lactobacillus acidophilus }\end{array}$ & $4.5 \times 10^{11}$ & $\begin{array}{l}\text { SBP, DBP, } \\
\text { Chol, TG }\end{array}$ & $\begin{array}{l}\text { Cholesterol, SBP and DBP pressure were significantly decreased } \\
(P<0.05) \text { by probiotic yoghurt products }\end{array}$ \\
\hline $\begin{array}{l}\text { Asemi et al. } \\
\quad(2013)\end{array}$ & DB; Iran & 54 & $0(0)$ & T2D & $50.5 / 52.6$ & $9 / 18,9 / 18$ & Placebo capsule & $\begin{array}{l}\text { L. acidophilus, } L \text {. casei, } L \text {. } \\
\text { rhamnosus, } L \text {. bulgaricus, } B . \\
\text { breve, B. longum, Streptococcus } \\
\text { thermophilus } \\
\end{array}$ & $9.52 \times 10^{10}$ & $\begin{array}{l}\text { HbAlc, TC, } \\
\text { TAG, BMI }\end{array}$ & $\begin{array}{l}\text { Consumption of probiotic supplements prevented a rise in plasma } \\
\text { glucose }(P=0.01) \text {. }\end{array}$ \\
\hline $\begin{array}{l}\text { Cavallini et al. } \\
\quad(2016)\end{array}$ & DB; Brazil & 49 & $0(0)$ & HCL & $\begin{array}{l}\text { (1) } 48.1 / 45.4,(2) \\
45.1 / 45.4\end{array}$ & $\begin{array}{l}\text { (1) } 17 / 0, \text {, (2) } 17 / 0 \text {, } \\
15 / 0\end{array}$ & $\begin{array}{l}\text { Placebo } \\
\text { unfermented soy } \\
\text { product }\end{array}$ & $\begin{array}{l}\text { (I) E. faecium, L. helveticus, } \\
\text { withou Issoflain, (2) E. faecium, } \\
\text { L. helveticus, with Isoflavin } \\
\text { (genistin, genistein, daidzin, } \\
\text { daidzein) }\end{array}$ & $\begin{array}{l}\text { (1) } 2 \times 10^{10} \\
\text { (2) } 2 \times 10^{10}\end{array}$ & TC, TAG & $\begin{array}{l}\text { The probiotic with Isoflavin group experienced significantly } \\
\text { reduced total cholesterol and } \operatorname{LDL}(P<0.05 \text { and } P<0.05 \\
\text { respectively), but not for the group without Isoflavin. }\end{array}$ \\
\hline $\begin{array}{l}\text { Ebrahimi et al. } \\
\text { (2017) }\end{array}$ & DB; Iran & 70 & $0(0)$ & T2D & $58.7 / 58.6$ & $23 / 12,19 / 26$ & Placebo capsule & $\begin{array}{c}\text { Lactobacillus family, } \\
\text { Bifidobacterium family, } \\
\text { Streptococcus thermophilus }\end{array}$ & $10^{9}$ & $\begin{array}{l}\text { FBG, Hblc, } \\
\text { BMI, TC, } \\
\text { TAG }\end{array}$ & $\begin{array}{l}\text { Probiotic supplementation significantly decreased plasma glucose } \\
\text { and Hblctc levels } \\
\qquad(P=0.05 \text { and } P<0.01 \text { respectively). }\end{array}$ \\
\hline $\begin{array}{l}\text { Ejtahed et al. } \\
\text { (2012) }\end{array}$ & DB; Iran & 64 & $4(6.25)$ & T2D & $50.9 / 51.0$ & $11 / 19,12 / 18$ & $\begin{array}{l}\text { Conventional } \\
\text { yogurt }\end{array}$ & B. lactis, L. acidophilus & $2.03 \times 10^{10}$ & $\begin{array}{l}\text { FBG, } \\
\text { HbAlc }\end{array}$ & $\begin{array}{l}\text { Consumption of probiotic yogurt significantly decreased plasma } \\
\text { glucose and HbAlc levels } \\
(P<0.01 \text { and } P<0.05 \text { respectively). }\end{array}$ \\
\hline $\begin{array}{l}\text { Feizollahzadeh et } \\
\text { al. (2017) }\end{array}$ & DB; Iran & 48 & $8(16.7)$ & T2D & $56.9 / 53.6$ & $9 / 11,10 / 10$ & Soymilk & L. plantarum A7) & $2 \times 10^{7}$ & FBG, TG & $\begin{array}{l}\text { In the probiotic group, there was a significant decrease in LDL } P \\
=0.023 \text { but no significant changes in plasma glucose. }\end{array}$ \\
\hline $\begin{array}{c}\text { Firouzi et al. } \\
\text { (2017) }\end{array}$ & DB; Malaysia & 136 & $35(25.74)$ & T2DM & $52.9 / 54.2$ & $31 / 17,34 / 19$ & $\begin{array}{c}\text { Placebo sachet } \\
\text { w/water }\end{array}$ & $\begin{array}{l}\text { L. acidophilus, L. cassei, L. lactis, } \\
\text { B. bifidum, B. longum, B. infantis }\end{array}$ & $3 \times 10^{10}$ & $\begin{array}{c}\text { All } \\
\text { Outcomes } \\
\end{array}$ & $\begin{array}{c}\text { No difference between probiotics and control group in all } \\
\text { variables }\end{array}$ \\
\hline $\begin{array}{c}\text { Gomes et al. } \\
\text { (2017) }\end{array}$ & DB; Brazil & 60 & $17(28.3)$ & $\mathrm{OW} / \mathrm{OB}$ & $20-59 / 20-59$ & $0 / 21.0 / 22$ & Placebo sachet & $\begin{array}{l}\text { L. acidophilus LA-14,L. casei } \\
\text { LC-1, Lactis LL-23, B. } \\
\text { bifidum BB-06, B. lactis BL-4 }\end{array}$ & $1 \times 10^{9}$ & $\begin{array}{l}\text { BMI, } \\
\text { HBA1C, } \\
\text { TC, TAG }\end{array}$ & $\begin{array}{l}\text { The probiotic group showed a greater decrease in BMI }(P< \\
0.001) \text {. No significant differences were observed in LDL or } \\
\text { triglyceride levels. }\end{array}$ \\
\hline Hata et al. (1996) & SB; Japan & 35 & $6(16.0)$ & OW, OB & $76.5 / 73$ & $4 / 13,4 / 9$ & Placebo & L. helveticus. S. cerevisae & $7.025 \times 10^{10}$ & $\begin{array}{l}\text { SBP, DBP, } \\
\text { Chol, TG }\end{array}$ & 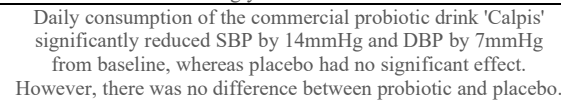 \\
\hline $\begin{array}{l}\text { Higashikawa et } \\
\text { al. (2016) }\end{array}$ & DB; Japan & 62 & $4(6.45)$ & ow & $\begin{array}{l}\text { (1) } 52.5 / 52.8,(2) \\
55.5 / 52.8\end{array}$ & $\begin{array}{l}\text { (1) } 8 / 13,7 / 13 \\
\text { (2) } 8 / 13,7 / 13 \\
\end{array}$ & Placebo powder & $\begin{array}{l}\text { (1) Pediococcus pentosaceus } \\
\text { LP28, (2) heat killed } \\
\text { Pediococcus pentosaceus } L P 28\end{array}$ & $\begin{array}{l}\text { (1) } 1 \times 10^{11} \\
\text { (2) } 1 \times 10^{11}\end{array}$ & $\begin{array}{l}\text { BMI, FPG, } \\
\text { HBAlc, TC, } \\
\text { TG }\end{array}$ & $\begin{array}{l}\text { For the heat-killed probiotic group only, there was a significant } \\
\text { decrease in BMI compared to placebo }(P=0.035) \text {. There were no } \\
\text { changes in plasma glucose, } \mathrm{HbAlc} \text { or serum lipids. }\end{array}$ \\
\hline $\begin{array}{c}\text { Inoue et al. } \\
(2003)\end{array}$ & SB; Japan & 39 & $4(10.26)$ & HTN & $56.2 / 53.9$ & $10 / 8,10 / 7$ & Placebo milk & $\begin{array}{l}\text { L. casei strain Shirota, L. lactis } \\
\text { YIT } 2027\end{array}$ & $<10 \times 10^{10}$ & $\begin{array}{l}\text { TC, TAG, } \\
\text { FBG, SBP, } \\
\text { DBP }\end{array}$ & $\begin{array}{l}\text { The probiotic group experienced a significant decrease in } \operatorname{SBP}(P \\
<0.05) \text {. }\end{array}$ \\
\hline Ivey et al. (2015) & DB; Australia & 116 & $0(.0)$ & $\mathrm{OW}, \mathrm{OB}$ & $\begin{array}{l}\text { (1) } 68.0 / 68.0,(2) \\
65.0 / 65.0\end{array}$ & $\begin{array}{l}\text { (1) } 25 / 15,23 / 17 \\
\text { (2) } 23 / 13,23 / 17\end{array}$ & $\begin{array}{l}\text { Control milk with } \\
\text { placebo capsule }\end{array}$ & 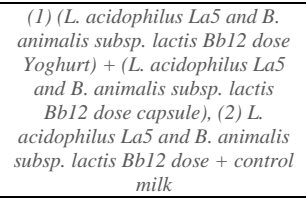 & $\begin{array}{l}\text { (1)1.2. } \times 10^{10} \\
(2) 6 \times 10^{9}\end{array}$ & $\begin{array}{l}\text { SBP, DBP, } \\
\text { Chol, BMI }\end{array}$ & $\begin{array}{l}\text { No difference between probiotics and control group in all } \\
\text { variables }\end{array}$ \\
\hline $\begin{array}{l}\text { Jones et al. } \\
(20120\end{array}$ & $\begin{array}{l}\text { DB; Czech } \\
\text { Republic }\end{array}$ & 120 & $11(9.2)$ & HCL & $51.9 / 48.7$ & $21 / 34,20 / 38$ & Placebo yoghurt & L. reuteri & $5 \times 10^{9}$ & Chol, TAG & $\begin{array}{l}\text { The probiotic group experienced significiant decreases in LDL anc } \\
\text { total cholesterol }(P=0.016 \text { and } P=0.031 \text { respectively). }\end{array}$ \\
\hline Jung et al. (2013) & DB; Korea & 62 & $8(12.9)$ & OW/OB & $19-60 / 19-60$ & $14 / 14,9 / 20$ & Placebo capsule & L. gasseri BNRI7 & $6 \times 10^{10}$ & $\begin{array}{c}\text { All } \\
\text { Outcomes }\end{array}$ & $\begin{array}{l}\text { No difference between probiotics and control group in all } \\
\text { variables }\end{array}$ \\
\hline $\begin{array}{l}\text { Kadooka et al. } \\
(2010)\end{array}$ & DB; Japan & 87 & $0(0)$ & $\mathrm{OB}$ & $48.3 / 49.2$ & $19 / 14,30 / 14$ & $\begin{array}{c}\text { Placebo } \\
\text { fermented milk }\end{array}$ & L. gasseri SBT2055 (LG2055 & $5 \times 10^{10}$ & BMI & $\begin{array}{c}\text { Consumption of probiotics significantly decreased BMI }(P< \\
0.001) \text {. }\end{array}$ \\
\hline $\begin{array}{l}\text { Kassaian et al. } \\
\quad(2018)\end{array}$ & DB; Iran & 91 & $35(29.2)$ & Pre-T2DM & $\begin{array}{l}\text { (1) } 53.0 / 53.0,(2) \\
53.0 / 53.0\end{array}$ & $\begin{array}{l}\text { (1) } 19 / 14,12 / 16 \\
\text { (2) } 13 / 17,12 / 16\end{array}$ & $\begin{array}{c}\text { Placebo } \\
\text { maltodextrin } \\
\text { powder }\end{array}$ & $\begin{array}{l}\text { (1) Probiotic } \\
\text { (L. acidophilus, B. lactis, }\end{array}$ & $\begin{array}{l}\text { (1) } 1 \times 10^{9} \\
\text { (2) } 1 \times 10^{9}\end{array}$ & $\begin{array}{l}\text { HBA1c, } \\
\text { FPG }\end{array}$ & 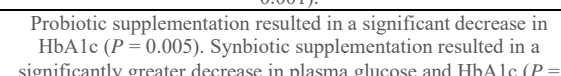 \\
\hline
\end{tabular}




\begin{tabular}{|c|c|c|c|c|c|c|c|c|c|c|c|}
\hline & & & & & & & & $\begin{array}{l}\text { B. bifidum, B. longum) } \\
\text { (2) Synbiotic (same bacteria) }\end{array}$ & & & $\begin{array}{c}0.01 \text { and } \\
P=0.008 \text { respectively }) .\end{array}$ \\
\hline Kim et al. (2017) & DB; Korea & 120 & $54(45)$ & ow & Not mentioned & Not mentioned & Placebo powder & $\begin{array}{l}\text { L. curvatus HY7601, } \\
\text { L. plantarum KY1032 }\end{array}$ & $2.5 \times 10^{9}$ & BMI & $\begin{array}{l}\text { Probiotics resulted in a significant reduction in BMI } \\
\qquad P=0.080) .\end{array}$ \\
\hline $\begin{array}{l}\text { Madjd et al. } \\
\text { (2016) }\end{array}$ & SB; Iran & 89 & $0(0)$ & $\mathrm{OB}$ & $32.2 / 31.8$ & $0 / 44,0 / 45$ & $\begin{array}{l}\text { Low-fat yoghurt, } \\
\text { S. thermophiles } \\
\text { and L. bulgaricus } \\
\text { (starter cultures), } \\
\text { hypo-energetic } \\
\text { diet }\end{array}$ & $\begin{array}{l}\text { S. thermophiles, } \\
\text { L. bulgaricus, L. acidophilus } \\
\text { LA5, B. lactis BB12 }\end{array}$ & $1 \times 10^{7}$ & $\begin{array}{l}\text { TC, } \\
\text { HBAIC, } \\
\text { FPG, TAG, } \\
\text { BMI }\end{array}$ & $\begin{array}{l}\text { The probiotic group had significantly greater decrease in total } \\
\text { cholesterol and } \mathrm{LL}(P=0.024 \text { and } P=0.018 \text { respectively). } \\
\text { There was no significicant difference in plasma glucose. }\end{array}$ \\
\hline Mafi et al. (2018) & DB; Iran & 60 & $6(10)$ & T2D & $58.9 / 60.9$ & Not mentioned & Placebo capsule & $\begin{array}{l}\text { L. acidophilus strain ZT-LI, B. } \\
\text { bifidum strain ZT-BI, } \\
\text { L. reuteri strain ZT-Lre, } \\
\text { L. fermentum strain ZT-L3 }\end{array}$ & $8 \times 10^{9}$ & $\begin{array}{l}\text { BMI, FPG, } \\
\text { HBA1C, } \\
\text { TAG, TC }\end{array}$ & $\begin{array}{l}\text { Probiotic supplementation resulted in a significant decrease in } \\
\text { plasma glucose and total triglycerides }(P=0.01 \text { and } P=0.001 \\
\text { respectively). }\end{array}$ \\
\hline $\begin{array}{l}\text { Mizushima et al. } \\
(2004)\end{array}$ & DB; Japan & 46 & $4(8.7)$ & HTN & $44.3 / 10.3$ & $23 / 0,23 / 0$ & $\begin{array}{c}\text { Placebo milk } \\
\text { (acidified) }\end{array}$ & L. helveticus. S cerevisiae & $7 \times 10^{11}, 2.5 \times 10^{9}$ & $\begin{array}{c}\text { SBP, DBP, } \\
\text { TC, TAG }\end{array}$ & $\begin{array}{l}\text { The probiotic group had a significant change in DBP } \\
\qquad(P=0.039) \text {. }\end{array}$ \\
\hline $\begin{array}{l}\text { Mobini et al. } \\
(2017)\end{array}$ & DB; Sweden & 44 & $0(0)$ & T2D, OB & $\begin{array}{l}\text { (1) } 66.0 / 65.0,(2) \\
64.0 / 65.0 \\
\end{array}$ & $\begin{array}{l}\text { (1) } 12 / 3,11 / 4 \\
\text { (2) } 11 / 3,11 / 4\end{array}$ & Placebo powder & $\begin{array}{l}\text { (1) Lactobacillus reuteri DSM } \\
\text { 17938, (2) Lactobacillus reuteri } \\
\text { DSM I7938 }\end{array}$ & $\begin{array}{l}\text { (1) } 1 \times 10^{8} \\
\text { (2) } 1 \times 10^{10}\end{array}$ & $\begin{array}{c}\text { All } \\
\text { Outcomes }\end{array}$ & $\begin{array}{c}\text { No difference between probiotics and control group in all } \\
\text { variables }\end{array}$ \\
\hline $\begin{array}{l}\text { Mohamadshahi et } \\
\text { al. (2018) }\end{array}$ & DB; Iran & 44 & $2(4.55)$ & $\mathrm{T} 2 \mathrm{M}, \mathrm{OW}$ or $\mathrm{OB}$ & $53.0 / 49.0$ & Not mentioned & $\begin{array}{c}\text { Placebo } \\
\text { conventional } \\
\text { yoghurt } \\
\text { (Lactobacillus } \\
\text { delbrueckii } \\
\text { subsp. bulgaricus } \\
\text { and } \\
\text { Streptococcus } \\
\text { thermophilus) } \\
\end{array}$ & $\begin{array}{l}\text { Bifidobacterium animalis subsp. } \\
\text { lactis Bb12 (DSM 10140) and } \\
\text { Lactobacillus acidophilus strain } \\
\text { La5 }\end{array}$ & $3.7 \times 10^{6}$ & $\begin{array}{l}\text { FBG, BMI, } \\
\text { HBA1C }\end{array}$ & $\begin{array}{l}\text { Consumption of probiotic yogurt significantly decreased } \mathrm{HbAlc} \\
\text { levels }(\mathrm{p}=0.032) \text {. }\end{array}$ \\
\hline $\begin{array}{l}\text { Mohammadi- } \\
\text { Sartang et al. } \\
\text { (2018) }\end{array}$ & DB; Iran & 44 & $2(4.7)$ & T2D, OW, OB & $53.0 / 49.0$ & $5 / 17,5 / 17$ & Placebo yogurt & $\begin{array}{l}\text { B. animal lactis Bb12+ } \\
\text { L. acidophilus La4 }\end{array}$ & $7.4 \times 10^{6}$ & $\begin{array}{l}\text { HBAlC, } \\
\text { BMI }\end{array}$ & $\begin{array}{c}\text { Consumption of probiotic yogurt resulted in a significant decrease } \\
\text { in triglyceride levels }(P=0.003) .\end{array}$ \\
\hline $\begin{array}{l}\text { Naito et al. } \\
\text { (2018) }\end{array}$ & DB; Japan & 100 & $2(2.0)$ & OB, pre-T2D & $48.6 / 47.4$ & $48 / 0.50 .0$ & Milk placebo & $\begin{array}{l}\text { Milk fermented with LCS YIT } \\
9029\end{array}$ & $1 \times 10^{11}$ & $\begin{array}{c}\text { All } \\
\text { Outcomes }\end{array}$ & $\begin{array}{l}\text { Daily administratation of a fermented milk product significantly } \\
\text { reduced plasma glucose, glycoalbumin and HbAlc at } 8 \text { weeks } \\
\text { commared with basseline } P<0.05 \text { ). However, this improvement } \\
\text { was only significantly better than placebo for glycoalbumin. } \\
\text { Subgroup analysis reveaeled improved benefitit for patients with } \\
\text { severe glucose intolerance. LDL was significantly lowered in the } \\
\text { probiotic group compared with control. }\end{array}$ \\
\hline $\begin{array}{l}\text { Ostadrahimi et al. } \\
\text { (2015) }\end{array}$ & DB; Iran & 60 & $0(0)$ & T2D & $35-65 / 5-65$ & Not mentioned & $\begin{array}{c}\text { Placebo } \\
\text { conventional } \\
\text { fermented milk }\end{array}$ & $\begin{array}{l}\text { L. acidophilus, L. casei, } \\
\quad \text { B. lactis }\end{array}$ & $\begin{array}{l}25 \times 10^{6}, 15 \times 10^{6} \\
8 \times 10^{6}\end{array}$ & $\begin{array}{l}\text { TC, TAG, } \\
\text { FPG, } \\
\text { HBAIC } \\
\end{array}$ & $\begin{array}{l}\text { The probiotic group had a significant decrease in blood glucose } \\
\text { and } \operatorname{HbAlc}(P=0.01 \text { and } P=0.02 \text { respectively). }\end{array}$ \\
\hline $\begin{array}{l}\text { Raygan et al. } \\
\text { (2018) }\end{array}$ & DB: Iran & 60 & $0(0)$ & T2D, CHD & $60.7 / 61.8$ & Not mentioned & Placebo capsules & $\begin{array}{l}\text { B. bifidum, L. casei, } \\
\text { L. acidophilus }\end{array}$ & $2 \times 10^{9}$ & $\begin{array}{l}\text { SBP, DBP, } \\
\text { BMI, FPG, } \\
\text { TAG, TC }\end{array}$ & $\begin{array}{l}\text { Probiotic supplementation significantly decreased plasma glucose } \\
\qquad(P=0.005) .\end{array}$ \\
\hline $\begin{array}{l}\text { Razmpoosh et al. } \\
\text { (2019) }\end{array}$ & DB; Iran & 68 & $8(11.8)$ & T2D & $58.6 / 61.3$ & $17 / 13,16 / 14$ & Placebo capsule & $\begin{array}{l}\text { L. acidophilus, L. cassei, } \\
\text { L. rhamnosus, L. bulgaricus, } B . \\
\text { breve, B. longum, } \\
\text { S. thermophilus } \\
\end{array}$ & $1.9 \times 10^{11}$ & $\begin{array}{l}\text { FPG, BMI, } \\
\text { TC, TAG }\end{array}$ & $\begin{array}{c}\text { There was a significant decrease in plasma glucose for the } \\
\text { probiotic group }(P=0.001) .\end{array}$ \\
\hline $\begin{array}{l}\text { Rezaei et al. } \\
\text { (2017) }\end{array}$ & DB; Iran & 90 & $0(0)$ & T2D & $50.5 / 50.1$ & $23 / 22,21 / 24$ & $\begin{array}{l}\text { Placebo yoghurt, } \\
\text { starter cultures } S . \\
\text { thermophilus, } L \text {. } \\
\text { bulgaricus }\end{array}$ & $\begin{array}{l}\text { L. acidophilus La5, } \\
\text { B. lactis Bb12 }\end{array}$ & $2.22 \times 10^{9}$ & $\begin{array}{l}\text { SBP, DBP, } \\
\text { FBG, TC, } \\
\text { TAG, } \\
\text { HBAAC }\end{array}$ & $\begin{array}{l}\text { The probiotic group experienced significant decreases in plasma } \\
\text { glucose, LDL, triglycerides, DBP and HbAlc levels }(P<0.05 \text { for } \\
\text { all }) \text {. }\end{array}$ \\
\hline $\begin{array}{l}\text { Shakeri et al. } \\
\text { (2014) }\end{array}$ & DB; Iran & 98 & $6(8.33)$ & T2D & $\begin{array}{c}\text { (1) } 52.3 / 53.1,(2) \\
52.3 / 53.1\end{array}$ & Not mentioned & Control bread & $\begin{array}{l}\text { (1) L. sporogenes, inulin (HPX), } \\
\text { (2) L. sporogenes }\end{array}$ & $\begin{array}{l}\text { (1) } 1.2 \times 10^{10}(2) \\
1.2 \times 10^{10}\end{array}$ & $\begin{array}{l}\text { BMI, FPG, } \\
\text { TAG, TC, }\end{array}$ & $\begin{array}{l}\text { Consumption of probiotic group with insulin resulted in a } \\
\text { significant decrease in triglycerides (op }=0.005) \text {. }\end{array}$ \\
\hline $\begin{array}{l}\text { Sharafedtinov et } \\
\text { al. (2013) }\end{array}$ & DB; Estonia & 40 & $4(10)$ & MetS & $10.9 / 12.1$ & $9 / 16,4 / 11$ & $\begin{array}{c}\text { Conventional } \\
\text { cheese }\end{array}$ & L. plantarum TENSIA & $2.55 \times 10^{10}$ & $\begin{array}{l}\begin{array}{l}\text { SBP, DBP, } \\
\text { BMI, Chol, } \\
\text { TG }\end{array} \\
\end{array}$ & $\begin{array}{l}\text { Probiotics significantly lowered BMI }(p=0.03) \text {, as well as DBP } \\
(p=0.02) ; \text { SBP was lowered, though not significant }\end{array}$ \\
\hline $\begin{array}{l}\text { Szulinska et al. } \\
\quad(2018)\end{array}$ & SB; Poland & 71 & $5(12.3)$ & $\begin{array}{c}\mathrm{OB}, \\
\text { (postmenopausal) }\end{array}$ & $\begin{array}{l}\text { (1) } 55.2 / 58.7,(2) \\
56.4 / 58.7\end{array}$ & $\begin{array}{l}\text { (1) } 0 / 23,0 / 24 \\
\text { (2) } 0 / 24,0 / 24\end{array}$ & Placebo powder & $\begin{array}{l}\text { (I) B. bifidum, } \\
\text { B. lactic WII, B. lactis W52, } L \text {. } \\
\text { acidophilus, L. brevis, } \\
\text { L. casei, L. Lalivarius, } \\
\text { L. lactis W19, } \\
\text { L. lactis W58), } \\
\text { (2) Same as previous }\end{array}$ & $\begin{array}{l}\text { (1) } 1 \times 11^{10} \\
\text { (2) } 2.5 \times 10^{9}\end{array}$ & $\begin{array}{l}\text { TC, BMI, } \\
\text { TAG, FPG }\end{array}$ & $\begin{array}{l}\text { Both high and low doses of probiotics significantly decreased } \\
\operatorname{SBP}(\mathrm{p}=0.0498 \text { and } \mathrm{p}=0.0359 \text { respectively). }\end{array}$ \\
\hline
\end{tabular}




\begin{tabular}{|c|c|c|c|c|c|c|c|c|c|c|c|}
\hline $\begin{array}{c}\text { Tajabadi- } \\
\text { Ebrahimi et al. } \\
(2017)\end{array}$ & DB; Iran & 60 & $5(8.3)$ & OW, T2D, CHD & $64.2 / 64.0$ & Not mentioned & Placebo capsule & $\begin{array}{l}\text { L. acidophilus, L. casei, } \\
\text { B. bifidum }\end{array}$ & $6 \times 10^{9}$ & $\begin{array}{l}\text { BMI, FPG, } \\
\text { TC, TAG }\end{array}$ & $\begin{array}{l}\text { Consumption of probiotics significantly decreased plasma glucose } \\
\qquad(\mathrm{p}=0.03)\end{array}$ \\
\hline $\begin{array}{l}\text { Zarrati et al. } \\
\quad(2014)\end{array}$ & DB; Iran & 75 & $0(0)$ & OW/OB & $36.0 / 36.0$ & Not mentioned & $\begin{array}{c}\text { Placebo yoghurt } \\
\text { (starter cultures } \\
\text { of } S \text {. } \\
\text { thermophilus and } \\
\text { L. bulgaricus.) } \\
\end{array}$ & $\begin{array}{l}\text { S. thermophilus. } \\
\text { L. bulgaricus, L. acidophilus } \\
\text { LA5, L. casei DNOOI, } \\
\text { B. lactis BB12 }\end{array}$ & $1 \times 10^{7}$ & $\begin{array}{l}\text { BMI, SBP, } \\
\text { DBP }\end{array}$ & $\begin{array}{l}\text { Probiotic yogurt resulted in a significant reduction in BMI ( } \mathrm{p}< \\
0.01) \text {. }\end{array}$ \\
\hline
\end{tabular}

Table 3. Subgroup Analysis of SBP and DBP

\begin{tabular}{|c|c|c|c|c|c|c|c|c|c|c|c|c|c|c|}
\hline \multirow[b]{2}{*}{ Subgroups } & \multicolumn{7}{|c|}{ SBP } & \multicolumn{7}{|c|}{ DBP } \\
\hline & $\begin{array}{c}\text { Studies, } \\
n\end{array}$ & Participants, $n$ & $I^{2}$ & Q-test & $\begin{array}{c}\text { Mean } \\
\text { Difference }\end{array}$ & $\overline{95 \% ~ C I ~}$ & $P$ & Studies, $n$ & Participants, $n$ & $I^{2}$ & Q-test & $\begin{array}{c}\text { Mean } \\
\text { Difference }\end{array}$ & $95 \% \mathrm{CI}$ & $P$ \\
\hline \multicolumn{15}{|l|}{ Health } \\
\hline $\mathrm{DM}$ & 2 & 191 & 28 & 0.24 & -5.82 & $-10.52,-1.12$ & 0.02 & 2 & 191 & 28 & 0.45 & -3.81 & $-5.68,-1.93$ & 0.0001 \\
\hline Obesity & 9 & 408 & 0 & 0.75 & -2.38 & $-0.59,-0.18$ & 0.03 & 9 & 408 & 0 & 0.38 & -2.07 & $-3.75,-0.38$ & 0.01 \\
\hline \multicolumn{15}{|l|}{ HTN } \\
\hline \multicolumn{15}{|c|}{ Hypercholesterolemia } \\
\hline Other & 4 & 144 & 0 & 0.92 & -0.78 & $-1.85,0.29$ & 0.15 & 4 & 144 & 0 & 0.75 & -1.64 & $-2.24,-1.03$ & 0.0001 \\
\hline \multicolumn{15}{|l|}{ Sex } \\
\hline $\mathrm{F}>\mathrm{M}$ & 7 & 273 & 68 & 0.04 & -2.64 & $-7.09,2.81$ & 0.25 & 7 & 273 & 68 & 0.06 & -2.29 & $-4.30,-0.27$ & 0.03 \\
\hline $\mathrm{F}<\mathrm{M}$ & 7 & 406 & 0 & 0.82 & -2.36 & $-4.74,0.03$ & 0.05 & 7 & 406 & 0 & 0.81 & -0.91 & $-3.30,-0.53$ & 0.007 \\
\hline \multirow{2}{*}{\multicolumn{15}{|c|}{$\begin{array}{l}\text { Dosage } \\
\quad<1.0 \times 10^{9} \mathrm{CFU} \\
\quad>1.0 \times 10^{9} \mathrm{CFU}\end{array}$}} \\
\hline & & & & & & & & & & & & & & \\
\hline \multirow{3}{*}{\multicolumn{15}{|c|}{$\begin{array}{l}\text { Attrition } \\
>15 \% \\
<15 \%\end{array}$}} \\
\hline & & & & & & & & & & & & & & \\
\hline & & & & & & & & & & & & & & \\
\hline Capsule & 5 & 173 & 0 & 0.92 & -0.31 & $-4.99,0.36$ & 0.90 & 5 & 173 & 0 & 0.80 & -0.25 & $-3.37,2.88$ & 0.88 \\
\hline Milk & 4 & 214 & 0 & 0.42 & -2.68 & $-5.81,0.44$ & 0.09 & 4 & 214 & 0 & 0.34 & -1.97 & $-4.52,0.58$ & 0.13 \\
\hline Yoghurt & 3 & 217 & 48 & 0.15 & -3.56 & $-7.43,0.31$ & 0.07 & 3 & 217 & 48 & 0.60 & -3.54 & $-5.13,-1.96$ & 0.001 \\
\hline Other & 4 & 185 & 0 & 0.71 & -0.88 & $-0.94,0.17$ & 0.10 & 4 & 185 & 0 & 0.77 & -1.68 & $-2.28,-1.08$ & 0.001 \\
\hline \multicolumn{15}{|l|}{ Blinding } \\
\hline \multicolumn{15}{|l|}{$\begin{array}{l}\text { SB } \\
\text { DR }\end{array}$} \\
\hline & & & & & & & & & & & & & & \\
\hline \multicolumn{15}{|l|}{ NB } \\
\hline \multicolumn{15}{|l|}{ Duration } \\
\hline$<1.5$ months & 5 & 293 & 41 & 0.15 & -2.00 & $-4.37,0.37$ & 0.10 & 5 & 293 & 41 & 0.21 & -2.14 & $-3.39,-0.89$ & 0.001 \\
\hline$>1.5$ months & 11 & 496 & 0 & 0.84 & -2.38 & $-4.60,-0.16$ & 0.04 & 11 & 496 & 0 & 0.64 & -1.98 & $-3.57,-0.38$ & 0.01 \\
\hline
\end{tabular}


Table 4. Subgroup Analysis of TC and TAG

\begin{tabular}{|c|c|c|c|c|c|c|c|c|c|c|c|c|c|c|}
\hline \multirow[b]{2}{*}{ Subgroups } & \multicolumn{7}{|c|}{ Total Cholesterol } & \multicolumn{7}{|c|}{$\begin{array}{l}\text { Triglycerides } \\
\end{array}$} \\
\hline & Studies, $n$ & Participants, $n$ & $I^{2}$ & Q-test & $\begin{array}{c}\text { Mean } \\
\text { Difference }\end{array}$ & $95 \% \mathrm{CI}$ & $P$ & Studies, $n$ & Participants, $n$ & $I^{2}$ & Q-test & $\begin{array}{c}\text { Mean } \\
\text { Difference }\end{array}$ & $95 \% \mathrm{CI}$ & $P$ \\
\hline \multicolumn{15}{|l|}{ Health } \\
\hline $\mathrm{DM}$ & 8 & 507 & 0 & 0.46 & -7.53 & $-13.59,-1.47$ & 0.01 & 9 & 547 & 22 & 0.26 & -14.17 & $-26.26,-2.08$ & 0.02 \\
\hline Obesity & 15 & 683 & 0 & 0.88 & -4.19 & $-7.28,-1.11$ & 0.008 & 15 & 663 & 74 & 0.01 & 7.51 & $-2.36,17.38$ & 0.14 \\
\hline HTN & 2 & 81 & 10 & 0.29 & -6.14 & $-20.05,7.77$ & 0.39 & 2 & 81 & 0 & 0.90 & 16.10 & $-41.50,73.71$ & 0.58 \\
\hline Hypercholesterolemia & 3 & 163 & 0 & 0.48 & -16.54 & $-25.46,-7.62$ & 0.0003 & 3 & 163 & 0 & 0.61 & -33.69 & $-91.36,23.98$ & 0.25 \\
\hline Other & 6 & 264 & 0 & 0.96 & -7.31 & $-14.94,0.32$ & 0.06 & 6 & 264 & 37 & 0.16 & -7.19 & $-27.64,13.27$ & 0.49 \\
\hline \multicolumn{15}{|l|}{ Sex } \\
\hline $\mathrm{F}>\mathrm{M}$ & 15 & 726 & 9 & 0.36 & -5.59 & $-9.08,-2.10$ & 0.002 & 16 & 746 & 74 & 0.001 & 7.26 & $-5.65,20.18$ & 0.27 \\
\hline $\mathrm{F}<\mathrm{M}$ & 12 & 620 & 0 & 0.61 & -6.44 & $-11.32,-1.57$ & 0.01 & 12 & 620 & 2 & 0.42 & 2.32 & $-3.06,7.70$ & 0.40 \\
\hline \multicolumn{15}{|l|}{ Dosage } \\
\hline$<1.0 \times 10^{9} \mathrm{CFU}$ & 4 & 194 & 0 & 0.83 & -3.67 & $-10.73,3.39$ & 0.31 & 5 & 234 & 0 & 0.97 & 1.04 & $-9.12,11.19$ & 0.84 \\
\hline$>1.0 \times 10^{9} \mathrm{CFU}$ & 30 & 1504 & 0 & 0.68 & -6.38 & $-8.98,-3.78$ & 0.0001 & 30 & 1484 & 68 & 0.001 & -2.70 & $-11.49,6.09$ & 0.55 \\
\hline \multicolumn{15}{|l|}{ Attrition } \\
\hline$>15 \%$ & 3 & 174 & 0 & 0.35 & -6.90 & $-18.43,4.62$ & 0.24 & 4 & 214 & 0 & 0.85 & -9.95 & $-23.51,3.61$ & 0.15 \\
\hline$<15 \%$ & 31 & 1524 & 0 & 0.75 & -6.01 & $-8.51,-3.52$ & 0.0001 & 31 & 1504 & 63 & 0.001 & -0.86 & $-9.01,7.30$ & 0.84 \\
\hline \multicolumn{15}{|l|}{ Form } \\
\hline Capsule & 10 & 477 & 0 & 0.72 & -3.00 & $-9.08,3.07$ & 0.33 & 10 & 477 & 23 & 0.26 & -7.18 & $-22.15,7.79$ & 0.35 \\
\hline Milk & 9 & 398 & 0 & 0.58 & -8.74 & $-14.62,-2.86$ & 0.004 & 10 & 438 & 0 & 00.88 & -6.99 & $-26.34,12.36$ & 0.48 \\
\hline Yoghurt & 5 & 393 & 0 & 0.31 & -9.48 & $-16.17,-2.48$ & 0.006 & 5 & 393 & 40 & 0.15 & 1.61 & $-6.50,9.71$ & 0.70 \\
\hline Other & 10 & 430 & 0 & 0.85 & -5.22 & $-8.63,-1.82$ & 0.003 & 10 & 410 & 84 & 0.001 & -1.36 & $-20.86,18.14$ & 0.89 \\
\hline \multicolumn{15}{|l|}{ Blinding } \\
\hline SB & 3 & 154 & 0 & 0.63 & -1.42 & $-10.29,7.46$ & 0.75 & 3 & 154 & 0 & 0.62 & 0.38 & $-10.27,11.03$ & 0.94 \\
\hline DB & 31 & 1544 & 0 & 0.78 & -6.43 & $-8.97,-3.89$ & 0.0001 & 32 & 1564 & 63 & 0.001 & -2.11 & $-10.49,6.27$ & 0.62 \\
\hline \multirow{2}{*}{\multicolumn{15}{|c|}{ Duration }} \\
\hline & & & & & & & & & & & & & & \\
\hline$<1.5$ months & 9 & 516 & 0 & 0.44 & -11.61 & $-17.37,-5.85$ & 0.0001 & 9 & 516 & 12 & 0.34 & 2.84 & $-3.78,9.45$ & 0.40 \\
\hline$>1.5$ months & 25 & 1182 & 0 & 0.96 & -4.84 & $-7.53,-2.14$ & 0.0004 & 26 & 1202 & 65 & 0.001 & -2.65 & $-12.42,7.12$ & 0.60 \\
\hline
\end{tabular}


Table 5. Subgroup Analysis of LDL-C and HDL-C

\begin{tabular}{|c|c|c|c|c|c|c|c|c|c|c|c|c|c|c|}
\hline \multirow[b]{2}{*}{ Subgroups } & \multicolumn{7}{|c|}{ LDL } & \multicolumn{7}{|c|}{ HDL } \\
\hline & $\begin{array}{c}\text { Studies, } \\
n\end{array}$ & Participants, $n$ & $I^{2}$ & Q-test & $\begin{array}{c}\text { Mean } \\
\text { Difference }\end{array}$ & $95 \% \mathrm{CI}$ & $P$ & Studies, $n$ & Participants, $n$ & $I^{2}$ & Q-test & $\begin{array}{c}\text { Mean } \\
\text { Difference }\end{array}$ & $95 \% \mathrm{CI}$ & $P$ \\
\hline \multicolumn{15}{|l|}{ Health } \\
\hline DM & 7 & 406 & 90 & 0.0001 & -8.09 & $-15.52,-0.65$ & 0.03 & 7 & 406 & 85 & 0.001 & 2.03 & $0.39,3.66$ & 0.01 \\
\hline Obesity & 12 & 562 & 60 & 0.01 & -7.27 & $-10.55,-3.99$ & 0.001 & 13 & 592 & 21 & 0.26 & -1.21 & $-1.93,-0.50$ & 0.001 \\
\hline \multicolumn{15}{|l|}{ HTN } \\
\hline Hypercholesterolemia & 3 & 163 & 49 & 0.14 & -20.67 & $-31.00,-10.34$ & 0.001 & 3 & 163 & 41 & 0.18 & 6.36 & $0.15,12.57$ & 0.04 \\
\hline Other & 6 & 264 & 0 & 0.58 & -5.61 & $-11.37,0.15$ & 0.06 & 6 & 264 & 76 & 0.001 & 1.26 & $-2.23,4.76$ & 0.48 \\
\hline \multicolumn{15}{|l|}{ Sex } \\
\hline $\mathrm{F}>\mathrm{M}$ & 12 & 605 & 79 & 0.001 & -9.87 & $-13.66,-6.08$ & 0.001 & 13 & 635 & 41 & 0.09 & -1.02 & $-1.88,-0.17$ & 0.02 \\
\hline $\mathrm{F}<\mathrm{M}$ & 9 & 438 & 53 & 0.03 & -6.35 & $-13.47,0.77$ & 0.08 & 10 & 484 & 30 & 0.17 & 1.22 & $-0.99,3.43$ & 0.28 \\
\hline \multicolumn{15}{|l|}{ Dosage } \\
\hline$<1.0 \times 10^{9} \mathrm{CFU}$ & 3 & 159 & 86 & 0.001 & -10.73 & $-25.58,4.13$ & 0.16 & 2 & 159 & 0 & 0.99 & 0.25 & $-1.20,1.70$ & 0.74 \\
\hline$>1.0 \times 10^{9} \mathrm{CFU}$ & 25 & 1236 & 78 & 0.001 & -8.38 & $-11.62,-5.13$ & 0.001 & 28 & 1312 & 91 & 0.001 & 1.16 & $-0.36,2.68$ & 0.13 \\
\hline \multicolumn{15}{|l|}{$\begin{array}{l}\text { Attrition } \\
>15 \% \\
<15 \%\end{array}$} \\
\hline \multicolumn{15}{|l|}{ Form } \\
\hline Capsule & 10 & 477 & 0 & 0.83 & -4.35 & $-6.87,-1.84$ & 0.007 & 10 & 477 & 85 & 0.001 & 1.95 & $-0.73,4.62$ & 0.15 \\
\hline Milk & 6 & 287 & 64 & 0.02 & -9.82 & $-18.28,-1.36$ & 0.02 & 8 & 363 & 52 & 0.05 & 0.86 & $-2.07,3.80$ & 0.56 \\
\hline Yoghurt & 4 & 370 & 52 & 0.10 & -18.06 & $-24.88,-11.24$ & 0.001 & 4 & 370 & 0 & 0.99 & 0.25 & $-1.82,2.32$ & 0.81 \\
\hline Other & 8 & 261 & 88 & 0.001 & -7.67 & $-13.16,-2.19$ & 0.006 & 8 & 261 & 97 & 0.001 & 0.32 & $-2.41,3.06$ & 0.82 \\
\hline \multicolumn{15}{|l|}{ Blinding } \\
\hline \multicolumn{15}{|l|}{ SB } \\
\hline \multicolumn{15}{|l|}{ DB } \\
\hline \multirow{2}{*}{\multicolumn{15}{|c|}{$\begin{array}{c}\text { NB } \\
\text { Duration }\end{array}$}} \\
\hline & & & & & & & & & & & & & & \\
\hline$<1.5$ months & 8 & 470 & 53 & 0.04 & -14.01 & $-20.67,-7.35$ & 0.001 & 9 & 516 & 49 & 0.05 & 0.61 & $-2.21,3.44$ & 0.67 \\
\hline$>1.5$ months & 20 & 925 & 81 & 0.001 & -7.08 & $-10.50,-3.66$ & 0.001 & 21 & 955 & 94 & 0.001 & 1.08 & $-0.56,2.72$ & 0.20 \\
\hline
\end{tabular}




\begin{tabular}{|c|c|c|c|c|c|c|c|c|c|c|c|c|c|c|}
\hline \multirow[b]{2}{*}{ Subgroups } & \multicolumn{7}{|c|}{ Fasting Glucose } & \multicolumn{7}{|c|}{ HbA1C } \\
\hline & $\begin{array}{c}\text { Studies, } \\
n\end{array}$ & Participants, $n$ & $I^{2}$ & Q-test & $\begin{array}{c}\text { Mean } \\
\text { Difference }\end{array}$ & $95 \% \mathrm{CI}$ & $P$ & Studies, $n$ & Participants, $n$ & $I^{2}$ & Q-test & $\begin{array}{c}\text { Mean } \\
\text { Difference }\end{array}$ & $95 \% \mathrm{CI}$ & $P$ \\
\hline \multicolumn{15}{|l|}{ Health } \\
\hline DM & 10 & 607 & 48 & 0.04 & -12.94 & $-20.75,-5.13$ & 0.001 & 6 & 435 & 94 & 0.001 & -0.35 & $-1.09,0.39$ & 0.36 \\
\hline Obesity & 7 & 377 & 63 & 0.01 & -1.60 & $-3.61,0.41$ & 0.12 & 6 & 349 & 0 & 0.64 & -0.02 & $-0.05,0.02$ & 0.31 \\
\hline \multicolumn{15}{|c|}{ HTN } \\
\hline \multicolumn{15}{|c|}{ Hypercholesterolemia } \\
\hline Other & 8 & 351 & 55 & 0.03 & -5.69 & $-6.30,-5.09$ & 0.001 & 7 & 275 & 91 & 0.001 & -0.32 & $-0.62,-0.01$ & 0.04 \\
\hline \multicolumn{15}{|l|}{ Sex } \\
\hline $\mathrm{F}>\mathrm{M}$ & 12 & 680 & 81 & 0.001 & -4.17 & $-5.12,-3.23$ & 0.001 & 11 & 584 & 92 & 0.001 & -0.18 & $-0.32,-0.05$ & 0.007 \\
\hline $\mathrm{F}<\mathrm{M}$ & 7 & 408 & 55 & 003 & -5.69 & $-6.30,-5.09$ & 0.001 & 5 & 313 & 76 & 0.002 & 0.13 & $-0.17,0.43$ & 0.40 \\
\hline \multicolumn{15}{|l|}{ Dosage } \\
\hline$<1.0 \times 10^{9} \mathrm{CFU}$ & 5 & 236 & 0 & 0.88 & -1.16 & $-4.24,1.92$ & 0.46 & 4 & 205 & 93 & 0.001 & -0.43 & $-1.01,0.15$ & 0.15 \\
\hline$>1.0 \times 10^{9} \mathrm{CFU}$ & 21 & 1134 & 85 & 0.001 & -5.29 & $-6.57,-4.01$ & 0.001 & 15 & 854 & 90 & 0.001 & -0.12 & $-0.24,0.01$ & 0.06 \\
\hline \multicolumn{15}{|l|}{ Attrition } \\
\hline$>15 \%$ & 4 & 226 & 0 & 0.97 & -5.63 & $-5.82,-5.43$ & 0.001 & 4 & 229 & 0 & 0.51 & -0.19 & $-0.25,-0.14$ & 0.001 \\
\hline$<15 \%$ & 22 & 1144 & 85 & 0.001 & -5.29 & $-6.57,-4.01$ & 0.001 & 15 & 830 & 92 & 0.001 & -0.20 & $-0.36,-0.04$ & 0.01 \\
\hline \multicolumn{15}{|l|}{ Form } \\
\hline Capsule & 7 & 421 & 67 & 0.006 & -13.47 & $-25.70,-1.24$ & 0.03 & 4 & 241 & 83 & 0.001 & 0.14 & $-0.15,0.44$ & 0.34 \\
\hline Milk & 4 & 233 & 95 & 0.001 & -7.54 & $-23.84,8.76$ & 0.36 & 2 & 158 & 98 & 0.001 & -0.61 & $-0.81,0.58$ & 0.31 \\
\hline Yoghurt & 5 & 304 & 62 & 0.01 & -12.88 & $-24.54,-1.22$ & 0.03 & 5 & 325 & 90 & 0.001 & -0.55 & $-1.03,-0.06$ & 0.03 \\
\hline Other & 10 & 412 & 80 & 0.001 & -4.41 & $-5.32,-3.51$ & 0.001 & 8 & 335 & 77 & 0.001 & -0.08 & $-0.17,0.02$ & 0.12 \\
\hline \multicolumn{15}{|l|}{ Blinding } \\
\hline SB & 2 & 124 & 32 & 0.23 & -3.15 & $-11.48,5.17$ & 0.46 & & & & & & & \\
\hline DB & 24 & 1246 & 83 & 0.001 & -5.27 & $-6.54,-4.00$ & 0.001 & & & & & & & \\
\hline NB & & & & & & & & & & & & & & \\
\hline \multicolumn{15}{|l|}{ Duration } \\
\hline$<1.5$ months & 3 & 210 & 0 & 0.84 & -16.15 & $-26.88,-5.42$ & 0.003 & 2 & 150 & 0 & 0.64 & -0.50 & $-0.87,-0.13$ & 0.009 \\
\hline$>1.5$ months & 23 & 1160 & 85 & 0.001 & -4.77 & $-6.01,-3.54$ & 0.001 & 17 & 909 & 92 & 0.001 & -0.16 & $-0.29,-0.03$ & 0.02 \\
\hline
\end{tabular}


Table 7. Subgroup Analysis of BMI

\begin{tabular}{|c|c|c|c|c|c|c|c|}
\hline \multirow[b]{2}{*}{ Subgroups } & \multicolumn{7}{|c|}{ BMI } \\
\hline & Studies, $n$ & Participants, $n$ & $I^{2}$ & Q-test & Mean Difference & 95\% CI & $P$ \\
\hline \multicolumn{8}{|l|}{ Health } \\
\hline DM & 6 & 357 & 0 & 0.99 & -0.33 & $-1.28,0.62$ & 0.49 \\
\hline Obesity & 11 & 623 & 0 & 0.84 & -0.48 & $-0.62,-0.35$ & 0.001 \\
\hline \multicolumn{8}{|l|}{ HTN } \\
\hline \multicolumn{8}{|c|}{ Hypercholesterolemia } \\
\hline Other & 8 & 350 & 0 & 0.99 & -0.09 & $-0.22,0.05$ & 0.21 \\
\hline \multicolumn{8}{|l|}{ Sex } \\
\hline $\mathrm{F}>\mathrm{M}$ & 11 & 526 & 47 & 0.04 & -0.35 & $-0.55,-0.15$ & 0.001 \\
\hline $\mathrm{F}<\mathrm{M}$ & 7 & 460 & 0 & 0.98 & -0.45 & $-1.03,0.14$ & 0.14 \\
\hline \multicolumn{8}{|l|}{ Dosage } \\
\hline$<1.0 \times 10^{9} \mathrm{CFU}$ & 4 & 205 & 0 & 0.99 & -0.08 & $-0.23,0.07$ & 0.31 \\
\hline$>1.0 \times 10^{9} \mathrm{CFU}$ & 21 & 1125 & 0 & 0.91 & -0.41 & $-0.53,-0.29$ & 0.001 \\
\hline \multicolumn{8}{|l|}{ Attrition } \\
\hline$>15 \%$ & 3 & 210 & 0 & 0.72 & -0.40 & $-1.01,0.21$ & 0.20 \\
\hline$<15 \%$ & 22 & 1120 & 7 & 0.37 & -0.29 & $-0.41,-0.18$ & 0.001 \\
\hline \multicolumn{8}{|l|}{ Form } \\
\hline Capsule & 7 & 421 & 0 & 0.99 & -0.11 & $-0.37,0.15$ & 0.42 \\
\hline \multicolumn{8}{|l|}{ Milk } \\
\hline Yoghurt & 5 & 248 & 0 & 0.96 & -0.09 & $-0.24,0.06$ & 0.24 \\
\hline Other & 11 & 476 & 0 & 0.95 & -0.50 & $-0.64,-0.36$ & 0.001 \\
\hline \multicolumn{8}{|l|}{ Blinding } \\
\hline \multicolumn{8}{|l|}{ SB } \\
\hline \multicolumn{8}{|l|}{ DB } \\
\hline \multicolumn{8}{|l|}{ NB } \\
\hline \multicolumn{8}{|l|}{ Duration } \\
\hline$<1.5$ months & 2 & 100 & 0 & 0.91 & -0.28 & $-1.92,1.36$ & 0.74 \\
\hline$>1.5$ months & 23 & 1230 & 6 & 0.38 & -0.30 & $-0.41,-0.18$ & 0.001 \\
\hline
\end{tabular}

Table 8. Egger's Test

\begin{tabular}{lcccc}
\hline Variable & Studies, $\mathbf{n}$ & $\mathbf{t}$ & $\mathbf{9 5 \%} \mathbf{C I}$ & $\boldsymbol{P}$ \\
\hline SBP & 13 & 1.36 & $-1.03,4.22$ & 0.205 \\
DBP & 13 & -0.53 & $-6.21,3.84$ & 0.611 \\
Total Cholesterol & 28 & -0.48 & $-2.15,1.34$ & 0.637 \\
Triglycerides & 29 & 0.63 & $-2.06,3.89$ & 0.533 \\
Glucose & 22 & -5.96 & $-12.54,-6.09$ & 0.001 \\
HbA1C & 16 & -0.86 & $-8.61,3.67$ & 0.403 \\
BMI & 21 & -1.63 & $-5.45,0.65$ & 0.117 \\
LDL & 21 & -1.93 & $-8.53,0.28$ & 0.066 \\
HDL & 23 & 1.27 & $-1.80,7.61$ & 0.215 \\
\hline
\end{tabular}




\section{References:}

Papers of particular interest, published recently, have been highlighted as:

* Of importance

** Of major importance

1. Who.int. (2020). Cardiovascular diseases (CVDs). [online] Available at: https://www.who.int/news-room/fact-sheets/detail/cardiovascular-diseases-(cvds) [Accessed 2 Feb. 2020].

2. Sacco RL, Roth GA, Reddy KS, Arnett DK, Bonita R, Gaziano TA, Heidenreich PA, Huffman MD, Mayosi BM, Mendis S, Murray CJ. The heart of 25 by 25: achieving the goal of reducing global and regional premature deaths from cardiovascular diseases and stroke: a modeling study from the American Heart Association and World Heart Federation. Circulation. 2016 Jun 7;133(23): e674-90.

3. Eckel RH, Grundy SM, Zimmet PZ. The metabolic syndrome. The lancet. 2005 Apr 16;365(9468):1415-28.

4. Zhang WW, Liu CY, Wang YJ, Xu ZQ, Chen Y, Zhou HD. Metabolic syndrome increases the risk of stroke: a 5-year follow-up study in a Chinese population. Journal of neurology. 2009 Sep 1;256(9):1493-9.

5. Saklayen MG. The global epidemic of the metabolic syndrome. Current hypertension reports. $2018 \mathrm{Feb} 1 ; 20(2): 12$.

6. Mancia G, Laurent S, Agabiti-Rosei E, Ambrosioni E, Burnier M, Caulfield MJ, Cifkova R, Clément D, Coca A, Dominiczak A, Erdine S. Reappraisal of European guidelines on hypertension management: a European Society of Hypertension Task Force document. Blood pressure. 2009 Jan 1;18(6):308-47.

7. Sacks FM, Svetkey LP, Vollmer WM, Appel LJ, Bray GA, Harsha D, Obarzanek E, Conlin PR, Miller ER, Simons-Morton DG, Karanja N. Effects on blood pressure of reduced dietary sodium and the Dietary Approaches to Stop Hypertension (DASH) diet. New England journal of medicine. 2001 Jan 4;344(1):3-10.

8. Eckburg PB, Bik EM, Bernstein CN, Purdom E, Dethlefsen L, Sargent M, Gill SR, Nelson KE, Relman DA. Diversity of the human intestinal microbial flora. science. 2005 Jun 10;308(5728):1635-8

9. Jandhyala SM, Talukdar R, Subramanyam C, Vuyyuru H, Sasikala M, Reddy DN. Role of the normal gut microbiota. World journal of gastroenterology: WJG. 2015 Aug 7;21(29):8787.

10. Tamboli CP, Neut C, Desreumaux P, Colombel JF. Dysbiosis in inflammatory bowel disease. Gut. 2004 Jan 1;53(1):1-4.

11. Sheflin AM, Whitney AK, Weir TL. Cancer-promoting effects of microbial dysbiosis. Current oncology reports. 2014 Oct 1;16(10):406.

12. Henao-Mejia J, Elinav E, Jin C, Hao L, Mehal WZ, Strowig T, Thaiss CA, Kau AL, Eisenbarth SC, Jurczak MJ, Camporez JP. Inflammasome-mediated dysbiosis regulates progression of NAFLD and obesity. Nature. 2012 Feb;482(7384):179-85.

13. ** Li X, Watanabe K, Kimura I. Gut microbiota dysbiosis drives and implies novel therapeutic strategies for diabetes mellitus and related metabolic diseases. Frontiers in immunology. 2017 Dec 20; 8:1882. This study revealed onset of diabetes is linked with microbiome dysbiosis, establishing a conceptual framework for treatment with probiotics. 
14. * Levy M, Kolodziejczyk AA, Thaiss CA, Elinav E. Dysbiosis and the immune system. Nature Reviews Immunology. 2017 Apr;17(4):219. This paper outlined the polymorphic relationship between genetic, lifestyle and a high-cholesterol diet with microbiome dysbiosis.

15. Yang T, Santisteban MM, Rodriguez V, Li E, Ahmari N, Carvajal JM, Zadeh M, Gong M, Qi Y, Zubcevic J, Sahay B. Gut dysbiosis is linked to hypertension. Hypertension. 2015 Jun;65(6):1331-40.

16. Le Chatelier E, Nielsen T, Qin J, Prifti E, Hildebrand F, Falony G, Almeida M, Arumugam M, Batto JM, Kennedy S, Leonard P. Richness of human gut microbiome correlates with metabolic markers. Nature. 2013 Aug;500(7464):541-6.

17. Hill C, Guarner F, Reid G, Gibson GR, Merenstein DJ, Pot B, Morelli L, Canani RB, Flint HJ, Salminen S, Calder PC. Expert consensus document: The International Scientific Association for Probiotics and Prebiotics consensus statement on the scope and appropriate use of the term probiotic. Nature reviews Gastroenterology \& hepatology. 2014 Aug;11(8):506-14.

18. Moayyedi P, Ford AC, Talley NJ, Cremonini F, Foxx-Orenstein AE, Brandt LJ, Quigley EM. The efficacy of probiotics in the treatment of irritable bowel syndrome: a systematic review. Gut. 2010 Mar 1;59(3):325-32.

19. D'souza AL, Rajkumar C, Cooke J, Bulpitt CJ. Probiotics in prevention of antibiotic associated diarrhoea: meta-analysis. Bmj. 2002 Jun 8;324(7350):1361.

20. Sazawal S, Hiremath G, Dhingra U, Malik P, Deb S, Black RE. Efficacy of probiotics in prevention of acute diarrhoea: a meta-analysis of masked, randomised, placebo-controlled trials. The Lancet infectious diseases. 2006 Jun 1;6(6):374-82.

21. Ambalam P, Raman M, Purama RK, Doble M. Probiotics, prebiotics and colorectal cancer prevention. Best practice \& research Clinical gastroenterology. $2016 \mathrm{Feb}$ 1;30(1):119-31.

22. Oak SJ, Jha R. The effects of probiotics in lactose intolerance: a systematic review. Critical reviews in food science and nutrition. 2019 Jun 17;59(11):1675-83.

23. Klein G, Pack A, Bonaparte C, Reuter G. Taxonomy and physiology of probiotic lactic acid bacteria. International journal of food microbiology. 1998 May 26;41(2):103-25.

24. Lye HS, Kuan CY, Ewe JA, Fung WY, Liong MT. The improvement of hypertension by probiotics: effects on cholesterol, diabetes, renin, and phytoestrogens. International journal of molecular sciences. 2009 Sep;10(9):3755-75.

25. Ng SC, Hart AL, Kamm MA, Stagg AJ, Knight SC. Mechanisms of action of probiotics: recent advances. Inflammatory bowel diseases. 2009 Feb 1;15(2):300-10.

26. McFarland LV. From yaks to yogurt: the history, development, and current use of probiotics. Clinical Infectious Diseases. 2015 May 15;60(suppl_2): S85-90.

27. Sun J, Buys N. Effects of probiotics consumption on lowering lipids and CVD risk factors: a systematic review and meta-analysis of randomized controlled trials. Annals of medicine. 2015 Aug 18;47(6):430-40.

28. ** Gomes AC, Bueno AA, de Souza RG, Mota JF. Gut microbiota, probiotics and diabetes. Nutrition journal. $2014 \mathrm{Dec} ; 13(1): 60$. This systematic review and metaanalysis demonstrated significant reductions in TC and BMI following probiotic treatment. Subgroup analyses further revealed that longer treatment duration and the use of multiple species were more efficacious in reducing TC than shorter treatment duration and the use of a single species.

29. Ettinger G, MacDonald K, Reid G, Burton JP. The influence of the human microbiome and probiotics on cardiovascular health. Gut microbes. 2014 Nov 2;5(6):719-28. 
30. Huang X, Lin J, Demner-Fushman D. Evaluation of PICO as a knowledge representation for clinical questions. InAMIA annual symposium proceedings 2006 (Vol. 2006, p. 359). American Medical Informatics Association.

31. ** Abbasi B, Mirlohi M, Daniali M, Ghiasvand R. Effects of probiotic soymilk on lipid panel in type 2 diabetic patients with nephropathy: A double-blind randomized clinical trial. Prog. Nutr. 2018 Jan 1; 20:70-8. This RCT demonstrated consumption of probiotic soymilk significantly reduced LDL-C and TAG in overweight patients, with greater effect than conventional soymilk.

32. Agerholm-Larsen L, Raben A, Haulrik N, Hansen AS, Manders M, Astrup A. Effect of 8week intake of probiotic milk products on risk factors for cardiovascular diseases. European journal of clinical nutrition. 2000 Apr;54(4):288-97.

33. Asemi Z, Zare Z, Shakeri H, Sabihi SS, Esmaillzadeh A. Effect of multispecies probiotic supplements on metabolic profiles, hs-CRP, and oxidative stress in patients with type 2 diabetes. Annals of nutrition and metabolism. 2013;63(1-2):1-9.

34. Cardoso Umbelino Cavallini D, Manzoni J, Simone M, Bedani R, Roselino MN, Celiberto LS, Vendramini RC, De Valdez GF, Saes Parra Abdalla D, Aparecida Pinto R, Rosetto D. Probiotic soy product supplemented with isoflavones improves the lipid profile of moderately hypercholesterolemic men: a randomized controlled trial. Nutrients. 2016 Jan;8(1):52.

35. sadat Ebrahimi Z, Nasli-Esfahani E, Nadjarzade A, Mozaffari-khosravi H. Effect of symbiotic supplementation on glycemic control, lipid profiles and microalbuminuria in patients with non-obese type 2 diabetes: a randomized, double-blind, clinical trial. Journal of Diabetes \& Metabolic Disorders. 2017 Dec;16(1):23.

36. Ejtahed HS, Mohtadi-Nia J, Homayouni-Rad A, Niafar M, Asghari-Jafarabadi M, Mofid V. Probiotic yogurt improves antioxidant status in type 2 diabetic patients. Nutrition. 2012 May 1;28(5):539-43.

37. * Feizollahzadeh S, Ghiasvand R, Rezaei A, Khanahmad H, Hariri M. Effect of probiotic soymilk on serum levels of adiponectin, inflammatory mediators, lipid profile, and fasting blood glucose among patients with type ii diabetes mellitus. Probiotics and antimicrobial proteins. 2017 Mar 1;9(1):41-7. This RCT demonstrated that consumption of probiotic soymilk resulted in no significant changes in triglyceride levels in participants with T2D.

38. ** Firouzi S, Majid HA, Ismail A, Kamaruddin NA, Barakatun-Nisak MY. Effect of multi-strain probiotics (multi-strain microbial cell preparation) on glycemic control and other diabetes-related outcomes in people with type 2 diabetes: a randomized controlled trial. European journal of nutrition. 2017 Jun 1;56(4):1535-50. This RCT involving individuals with T2D showed significant improvements in HbA1C without any significant decrease in FBG following consumption of probiotic powder. This study also demonstrated non-significant reductions in TG and TC levels, along with a significant reduction in SBP from baseline within the probiotics group.

39. Gomes AC, de Sousa RG, Botelho PB, Gomes TL, Prada PO, Mota JF. The additional effects of a probiotic mix on abdominal adiposity and antioxidant Status: a double-blind, randomized trial. Obesity. 2017 Jan;25(1):30-8.

40. Hata Y, Yamamoto M, Ohni M, Nakajima K, Nakamura Y, Takano T. A placebocontrolled study of the effect of sour milk on blood pressure in hypertensive subjects. The American journal of clinical nutrition. 1996 Nov 1;64(5):767-71.

41. Higashikawa F, Noda M, Awaya T, Danshiitsoodol N, Matoba Y, Kumagai T, Sugiyama M. Antiobesity effect of Pediococcus pentosaceus LP28 on overweight subjects: a randomized, double-blind, placebo-controlled clinical trial. European journal of clinical nutrition. 2016 May;70(5):582-7. 
42. Inoue K, Shirai T, Ochiai H, Kasao M, Hayakawa K, Kimura M, Sansawa H. Bloodpressure-lowering effect of a novel fermented milk containing $\gamma$-aminobutyric acid (GABA) in mild hypertensives. European journal of clinical nutrition. 2003 Mar;57(3):490-5.

43. Ivey KL, Hodgson JM, Kerr DA, Thompson PL, Stojceski B, Prince RL. The effect of yoghurt and its probiotics on blood pressure and serum lipid profile; a randomised controlled trial. Nutrition, Metabolism and Cardiovascular Diseases. 2015 Jan 1;25(1):4651 .

44. Jones ML, Martoni CJ, Parent M, Prakash S. Cholesterol-lowering efficacy of a microencapsulated bile salt hydrolase-active Lactobacillus reuteri NCIMB 30242 yoghurt formulation in hypercholesterolaemic adults. British Journal of Nutrition. 2012 May;107(10):1505-13.

45. Jung SP, Lee KM, Kang JH, Yun SI, Park HO, Moon Y, Kim JY. Effect of Lactobacillus gasseri BNR17 on overweight and obese adults: a randomized, double-blind clinical trial. Korean journal of family medicine. 2013 Mar;34(2):80.

46. Kadooka Y, Sato M, Imaizumi K, Ogawa A, Ikuyama K, Akai Y, Okano M, Kagoshima M, Tsuchida T. Regulation of abdominal adiposity by probiotics (Lactobacillus gasseri SBT2055) in adults with obese tendencies in a randomized controlled trial. European journal of clinical nutrition. 2010 Jun;64(6):636-43.

47. * Kassaian N, Feizi A, Aminorroaya A, Jafari P, Ebrahimi MT, Amini M. The effects of probiotics and synbiotic supplementation on glucose and insulin metabolism in adults with prediabetes: a double-blind randomized clinical trial. Acta diabetologica. 2018 Oct 1;55(10):1019-28. This RCT observed the effects of probiotic/symbiotic supplementation on pre-diabetic participants. Intervention resulted in significant improvements in FBG and HbA1c levels.

48. ** Kim M, Kim M, Kang M, Yoo HJ, Kim MS, Ahn YT, Sim JH, Jee SH, Lee JH. Effects of weight loss using supplementation with Lactobacillus strains on body fat and medium chain acylcarnitines in overweight individuals. Food \& function. 2017;8(1):25061. This RCT showed a significant reduction in BMI in overweight participants who consumed probiotic supplement.

49. Madjd A, Taylor MA, Mousavi N, Delavari A, Malekzadeh R, Macdonald IA, Farshchi HR. Comparison of the effect of daily consumption of probiotic compared with low-fat conventional yogurt on weight loss in healthy obese women following an energyrestricted diet: a randomized controlled trial. The American journal of clinical nutrition. 2016 Feb 1;103(2):323-9.

50. * Mafi A, Namazi G, Soleimani A, Bahmani F, Aghadavod E, Asemi Z. Metabolic and genetic response to probiotics supplementation in patients with diabetic nephropathy: a randomized, double-blind, placebo-controlled trial. Food \& function. 2018;9(9):4763-70.

This RCT enrolled individuals with T2D. When compared to placebo, probiotic supplementation resulted in significant reductions in FBG and TG, along with nonsignificant reductions in $\mathrm{HbA1c}$ and $\mathrm{TC}$.

51. Mizushima S, Ohshige K, Watanabe J, Kimura M, Kadowaki T, Nakamura Y, Tochikubo O, Ueshima H. Randomized controlled trial of sour milk on blood pressure in borderline hypertensive men. American journal of hypertension. 2004 Aug 1;17(8):701-6.

52. * Mobini R, Tremaroli V, Ståhlman M, Karlsson F, Levin M, Ljungberg M, Sohlin M, Bertéus Forslund H, Perkins R, Bäckhed F, Jansson PA. Metabolic effects of L actobacillus reuteri DSM 17938 in people with type 2 diabetes: A randomized controlled trial. Diabetes, Obesity and Metabolism. 2017 Apr;19(4):579-89. This study enrolled patients with T2D but demonstrated no significant differences between placebo and probiotic groups in all variables. 
53. Mohamadshahi M, Veissi M, Haidari F, Shahbazian H, Kaydani GA, Mohammadi F. Effects of probiotic yogurt consumption on inflammatory biomarkers in patients with type 2 diabetes. BioImpacts: BI. 2014;4(2):83.

54. Mohammadi-Sartang M, Bellissimo N, de Zepetnek JT, Brett NR, Mazloomi SM, Fararouie M, Bedeltavana A, Famouri M, Mazloom Z. The effect of daily fortified yogurt consumption on weight loss in adults with metabolic syndrome: A 10-week randomized controlled trial. Nutrition, Metabolism and Cardiovascular Diseases. 2018 Jun 1;28(6):565-74.

55. Naito E, Yoshida Y, Kunihiro S, Makino K, Kasahara K, Kounoshi Y, Aida M, Hoshi R, Watanabe O, Igarashi T, Miyazaki K. Effect of Lactobacillus casei strain Shirotafermented milk on metabolic abnormalities in obese prediabetic Japanese men: a randomised, double-blind, placebo-controlled trial. Bioscience of microbiota, food and health. 2017:17-012.

56. Ostadrahimi A, Taghizadeh A, Mobasseri M, Farrin N, Payahoo L, Gheshlaghi ZB, Vahedjabbari M. Effect of probiotic fermented milk (kefir) on glycemic control and lipid profile in type 2 diabetic patients: a randomized double-blind placebo-controlled clinical trial. Iranian journal of public health. 2015 Feb;44(2):228.

57. Raygan F, Rezavandi Z, Bahmani F, Ostadmohammadi V, Mansournia MA, TajabadiEbrahimi M, Borzabadi S, Asemi Z. The effects of probiotic supplementation on metabolic status in type 2 diabetic patients with coronary heart disease. Diabetology \& metabolic syndrome. 2018 Dec 1;10(1):51.

58. * Razmpoosh E, Javadi A, Ejtahed HS, Mirmiran P, Javadi M, Yousefinejad A. The effect of probiotic supplementation on glycemic control and lipid profile in patients with type 2 diabetes: A randomized placebo-controlled trial. Diabetes \& Metabolic Syndrome: Clinical Research \& Reviews. 2019 Jan 1;13(1):175-82. This RCT revealed a significant decrease in FPG and a significant increase in HDL-C following multistrain probiotic supplementation in patients with Type 2 diabetes.

59. ** Rezaei M, Sanagoo A, Jouybari L, Behnampoo N, Kavosi A. The effect of probiotic yogurt on blood glucose and cardiovascular biomarkers in patients with type II diabetes: a randomized controlled trial. Evidence Based Care. 2017;6(4):26-35. Significant reductions in FBG, TG, DBP, and HbA1c were revealed in this RCT following consumption of probiotic yogurt in patients with T2D.

60. Sharafedtinov KK, Plotnikova OA, Alexeeva RI, Sentsova TB, Songisepp E, Stsepetova J, Smidt I, Mikelsaar M. Hypocaloric diet supplemented with probiotic cheese improves body mass index and blood pressure indices of obese hypertensive patients-a randomized double-blind placebo-controlled pilot study. Nutrition journal. 2013 Dec 1;12(1):138.

61. Shakeri H, Hadaegh H, Abedi F, Tajabadi-Ebrahimi M, Mazroii N, Ghandi Y, Asemi Z. Consumption of synbiotic bread decreases triacylglycerol and VLDL levels while increasing HDL levels in serum from patients with type-2 diabetes. Lipids. 2014 Jul;49(7):695-701.

62. * Szulińska M, Łoniewski I, Skrypnik K, Sobieska M, Korybalska K, Suliburska J, Bogdański P. Multispecies probiotic supplementation favorably affects vascular function and reduces arterial stiffness in obese postmenopausal women-A 12-week placebocontrolled and randomized clinical study. Nutrients. 2018 Nov;10(11): 1672. This RCT revealed a significant reduction in SBP following probiotic supplementation in obese postmenopausal women.

63. ** Tajabadi-Ebrahimi M, Sharifi N, Farrokhian A, Raygan F, Karamali F, Razzaghi R, Taheri S, Asemi Z. A randomized controlled clinical trial investigating the effect of synbiotic administration on markers of insulin metabolism and lipid profiles in overweight type 2 diabetic patients with coronary heart disease. Experimental and 
Clinical Endocrinology \& Diabetes. 2017 Jan;125(01):21-7. This RCT showed a significant decrease in FPG and a significant increase in HDL-C levels following synbiotic supplementation in overweight, type 2 diabetic patients with coronary heart disease.

64. Zarrati M, Salehi E, Nourijelyani K, Mofid V, Zadeh MJ, Najafi F, Ghaflati Z, Bidad K, Chamari M, Karimi M, Shidfar F. Effects of probiotic yogurt on fat distribution and gene expression of proinflammatory factors in peripheral blood mononuclear cells in overweight and obese people with or without weight-loss diet. Journal of the American College of Nutrition. 2014 Nov 2;33(6):417-25.

65. Kantor ED, Rehm CD, Haas JS, Chan AT, Giovannucci EL. Trends in prescription drug use among adults in the United States from 1999-2012. Jama. 2015 Nov 3;314(17):181830 .

66. Khalesi S, Sun J, Buys N, Jayasinghe R. Effect of probiotics on blood pressure: a systematic review and meta-analysis of randomized, controlled trials. Hypertension. 2014 Oct;64(4):897-903.

67. Wang L, Guo MJ, Gao Q, Yang JF, Yang L, Pang XL, Jiang XJ. The effects of probiotics on total cholesterol: A meta-analysis of randomized controlled trials. Medicine. 2018 Feb;97(5).

68. Ahn HY, Kim M, Ahn YT, Sim JH, Choi ID, Lee SH, Lee JH. The triglyceride-lowering effect of supplementation with dual probiotic strains, Lactobacillus curvatus HY7601 and Lactobacillus plantarum KY1032: Reduction of fasting plasma lysophosphatidylcholines in nondiabetic and hypertriglyceridemic subjects. Nutrition, Metabolism and Cardiovascular Diseases. 2015 Aug 1;25(8):724-33.

69. Pereira DI, Gibson GR. Effects of consumption of probiotics and prebiotics on serum lipid levels in humans. Critical reviews in biochemistry and molecular biology. 2002 Jan 1;37(4):259-81.

70. Yao K, Zeng L, He Q, Wang W, Lei J, Zou X. Effect of probiotics on glucose and lipid metabolism in type 2 diabetes mellitus: a meta-analysis of 12 randomized controlled trials. Medical science monitor: international medical journal of experimental and clinical research. 2017; 23:3044.

71. Zhang Q, Wu Y, Fei X. Effect of probiotics on glucose metabolism in patients with type 2 diabetes mellitus: A meta-analysis of randomized controlled trials. Medicina. 2016 Feb;52(1):28-34.

72. John GK, Wang L, Nanavati J, Singh R, Mullin G. Mo1963-Lactobacillus Probiotics Reduce Body Mass Index, Body Weight, and Fat Mass in Overweight and Obese Subjects: A Systematic Review and Meta-Analysis of Randomized Controlled Trials. Gastroenterology. 2018 May 1;154(6):S-865.

73. Hernán MA, Hernández-Díaz S, Robins JM. A structural approach to selection bias. Epidemiology. 2004 Sep 1:615-25.

74. Zubillaga M, Weill R, Postaire E, Goldman C, Caro R, Boccio J. Effect of probiotics and functional foods and their use in different diseases. Nutrition Research. 2001 Mar 1;21(3):569-79.

75. Barichella M, Pacchetti C, Bolliri C, Cassani E, Iorio L, Pusani C, Pinelli G, Privitera G, Cesari I, Faierman SA, Caccialanza R. Probiotics and prebiotic fiber for constipation associated with Parkinson disease: an RCT. Neurology. 2016 Sep 20;87(12):1274-80.

76. Gremeaux V, Drigny J, Nigam A, Juneau M, Guilbeault V, Latour E, Gayda M. Longterm lifestyle intervention with optimized high-intensity interval training improves body composition, cardiometabolic risk, and exercise parameters in patients with abdominal obesity. American Journal of Physical Medicine \& Rehabilitation. 2012 Nov $1 ; 91(11): 941-50$. 
77. Dimidi E, Christodoulides S, Scott SM, Whelan K. Mechanisms of action of probiotics and the gastrointestinal microbiota on gut motility and constipation. Advances in Nutrition. 2017 May;8(3):484-94.

78. Baker JM, Al-Nakkash L, Herbst-Kralovetz MM. Estrogen-gut microbiome axis: physiological and clinical implications. Maturitas. 2017 Sep 1; 103:45-53. 